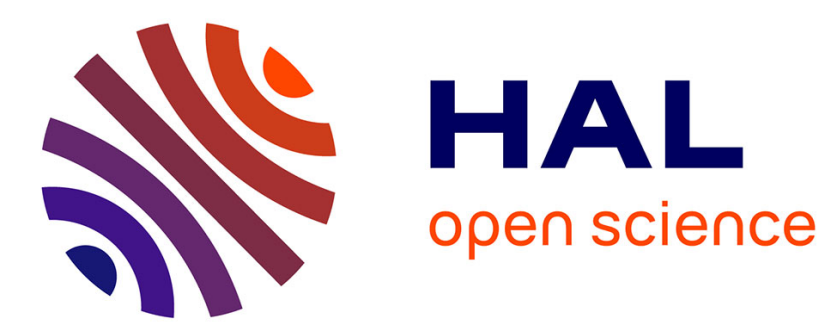

\title{
Trust and Financial Development: Forms of Trust and Ethnic Fractionalization Matter
}

\author{
Ali Recayi Ogcem, Ruth Tacneng, Amine Tarazi
}

\section{To cite this version:}

Ali Recayi Ogcem, Ruth Tacneng, Amine Tarazi. Trust and Financial Development: Forms of Trust and Ethnic Fractionalization Matter. 2021. hal-03322592

\author{
HAL Id: hal-03322592 \\ https://hal.science/hal-03322592 \\ Preprint submitted on 19 Aug 2021
}

HAL is a multi-disciplinary open access archive for the deposit and dissemination of scientific research documents, whether they are published or not. The documents may come from teaching and research institutions in France or abroad, or from public or private research centers.
L'archive ouverte pluridisciplinaire HAL, est destinée au dépôt et à la diffusion de documents scientifiques de niveau recherche, publiés ou non, émanant des établissements d'enseignement et de recherche français ou étrangers, des laboratoires publics ou privés. 


\title{
Trust and Financial Development: Forms of Trust and Ethnic Fractionalization Matter
}

\author{
Ali Recayi OGCEM ${ }^{1 \mathrm{a}}$; Ruth TACNENG ${ }^{\text {a; }}$ Amine TARAZI ${ }^{\text {ab; }}$; \\ a Université de Limoges, LAPE, 5 rue Félix Eboué, 87031 Limoges Cedex 1, France \\ b Institut Universitaire de France (IUF), 1 rue Descartes, 75231 Paris Cedex 05, France
}

This version: July 15, 2021

\begin{abstract}
We examine the relationship between trust and financial development using detailed regional data in Turkey. We distinguish different forms of trust (i.e., generalized, narrow, and wide) and investigate whether varying degrees of generalized and narrow trust, as well as wide and narrow trust imply different financial development outcomes. Moreover, we assess how different forms of trust and their combination affect financial development in the presence of ethnically fragmented populations. We use instrumental variable (IV) estimations to address endogeneity issues and the potential reverse causality between trust and financial development. Our main results indicate that wide trust has a significantly positive impact on financial development. Moreover, in regions where narrow trust is relatively high, we find financial development benefits from increasing generalized trust. Our findings also highlight that whereas wide trust leads to more developed financial markets in more ethnically fragmented regions, generalized trust plays a stronger role in less fragmented ones. Further, we also analyze the impact of trust on the proportion of credit backed by stable funds such as deposits. Our findings show that generalized trust plays an important role in mitigating the adverse effects that ethnic fractionalization have on the availability of deposits or stable sources to fund loans. On the whole, our study highlights the importance of distinguishing the impact of different forms and combinations of trust. Generalized trust, which is the focus of most studies, is not an all-encompassing one-size-fits-all solution to enhance economic performance.
\end{abstract}

Keywords: Trust, Financial development, Regional development, Ethnic fractionalization

JEL Classification : G21, G28, O16, Z13

Corresponding author. Tel: +33555149251

*Email: A.R. Ogcem (ali.ogcem@etu.unilim.fr), A. Tarazi (amine.tarazi@unilim.fr), R. Tacneng (ruth.tacneng@unilim.fr) 


\section{Introduction}

Trust plays a crucial role in market and societal development. Putnam (1993), for example, argues that social capital, which encompasses norms, trust, and social networks, determines the performance of an economic system. In particular, an economy with strong interconnected networks of trust enables social collective actions and encourages attitudes that enhance cooperation. Trust also plays an important role in business creation by enabling knowledge spillovers and by improving economic efficiency (Corradini, 2020). Arrow (1972) states that trust is fundamental in every commercial transaction, especially those that require long-term commitments. This is primarily the case for financial contracts, which are trustintensive. Recent empirical studies, moreover, show the crucial role of trust in promoting efficient contracting by decreasing the need for contract regulation and by providing a viable alternative to formal contract enforcement (Cline and Williamson, 2020).

Trust is essential for a wide range of economic outcomes, including financial development. Several studies show a positive link between trust and the use of formal finance instruments (Guiso et al., 2004), stock market participation and development (Guiso et al., 2008; $\mathrm{Ng}$ et al., 2016), investor responsiveness to corporate announcements (Pevzner et al., 2015), lower probabilities of default (Jiang and Lim, 2018), reduced macroeconomic volatility (Sangnier, 2013), total factor productivity growth (Bjørnskov and Méon, 2015), market integration (Tu and Bulte, 2010), and investment rate (Zak and Knack, 2001). We note, however, that there are important challenges in explaining the relationships among trust, finance, and economic development, mainly due to trust measurement problems and identification issues. Guiso et al. (2008) and Algan and Cahuc (2014) argue that trust is different from risk aversion or optimism. Trust has indeed its own distinctive characteristics that interact with financial products in a largely unique manner. They purport that the financial environment, which depends on institutional quality, and trustee characteristics could influence trust.

The literature mainly distinguishes generalized trust from particularized trust, which results in different social and economic outcomes (Coleman, 1990; Fukuyama, 1995; Uslaner, 2002; Delhey et al., 2011). Moreover, we note the growing recent research focusing on the multidimensional nature of trust, as well as on the relationship between different aspects of trust (Freitag and Traunmüller, 2009; Delhey et al., 2011; Braesemann and Stephany, 2021). Particularized trust, or a narrow trust radius, is trust in familiar people or in an individual's inner circle, such as relatives, friends, and close acquaintances (in-group trust). Moreover, generalized trust encompasses one's expectations of the general population's trustworthiness. The concept depends, however, on one's connotation of "most people." Studying the radius of "most people" refers to the standard generalized trust measure from the World Values Survey (WVS), Delhey et al. (2011) find that although "most people" signifies out-groups in the majority of countries they study, the notion in most Confucian countries is much more restricted. Its inclination toward a narrow or wide trust radius is less clear in countries such as South Africa, Turkey, and Peru. We note that a wide trust radius refers to trust in people not known personally, such as those with different group identities (i.e., nationality, religion, or ethnic affiliation) (out-group trust).

Accordingly, the importance of the trust dimensions could be linked to the level of societal fragmentation. On one hand, ethnic diversity may cause governmental inefficiency, which leads to social conflicts (Alesina and La Ferrara, 2005). Consequently, institutional weakness may result in lack of sufficient interaction in society, thereby increasing the information asymmetry between financial institutions and households. On the other hand, other scholars suggest that ethnic diversity brings various abilities, experiences, flexibility, and know-how that may lead to higher innovation and productivity (Alesina et al., 1999).

The purpose of this research is threefold. First, we examine how the different forms of trust (generalized, wide, and narrow) affect regional financial development in the context of a single emerging economy 
where religion is strongly present, along with significant ethnical heterogeneity. We note that many other institutional factors affect the use and availability of financial contracts across countries; these factors are often difficult to control for in a regression analysis. In this study, we exploit within-country variations to identify how trust affects the use of financial contracts. We study Turkey, which is predominantly composed of Turkish (75\%-80\%) and Kurdish (15\%-20\%) ethnic groups and carries significant ethnic heterogeneity across regions with large variations in economic and financial development. Such a setting makes it ideal to investigate the different forms of trust. Moreover, although the literature mostly focuses on generalized trust, we stress the importance of investigating the distinct contributions of narrow and wide trust on financial development.

Second, we analyze how the interactions of generalized trust with narrow trust, and of wide trust with narrow trust affect financial development. More specifically, we investigate whether various trust dimensions are complements or drive one another out. To our knowledge, we are the first to study whether specific combinations of trust forms are linked to better financial development outcomes. Finally, we analyze whether the impact of trust on financial development depends on the level of ethnic fractionalization. As such, our study contributes to the literature by providing a better understanding of the importance of a wide trust radius, such as out-group trust, on financial development outcomes, especially where fragmentation may be high. Indeed, such settings make one's social identity more pronounced and antagonism toward "others" more likely. We also examine further issues and conduct robustness checks by looking into the trust-in-banks dimension and by investigating how trust affects the credit-to-deposit ratio. We thus analyze whether trust affects the need to rely on external, unstable funding sources to finance lending activities.

We address endogeneity concerns with regard to our trust variables by using the instrumental variable estimation method. Using the number of foundations and neighboring regions' trust measures as instruments, our results indicate a positive, significant impact of wide trust on financial development. Moreover, we find generalized trust is complementary to narrow trust in positively affecting the level of financial development. These results confirm that trust matters for financial development, but they also highlight that a better understanding of the different dimensions of trust in a community is key to finding which ones are more likely to support financial development. In terms of the interaction between ethnic heterogeneity or fractionalization and our trust measures, our findings indicate that strengthening generalized trust is crucial for financial development in less fractionalized regions, while increasing wide trust is vital in more fragmented areas. Our findings also indicate the importance of generalized trust and wide trust in enhancing stable fund availability as a proportion of credit in regions where narrow trust is very high. We highlight the positive influence of generalized trust on credit intermediation even in more ethnically fragmented areas.

The rest of the paper is laid out as follows. Section 2 reviews the related literature and presents our research focus. Section 3 discusses the data used in the econometric analyses. Section 4 presents our empirical methodology and the results. Section 5 is dedicated to robustness checks, and section 6 concludes the paper.

\section{Related Literature and Research Focus}

\subsection{Forms of Trust}

Although trust was initially thought to be a one-dimensional concept that produces only positive outcomes, it is now generally acknowledged that different forms or radii of trust exist that can produce an array of results. Several studies identify a dichotomy of trust according to social scope: generalized trust and particularized trust (Uslaner, 2002), likened respectively to a distinction between two types of 
social capital: bridging and bonding (Putnam, 2000). While bridging social capital refers to the bonds across diverse social groups, bonding social capital pertains to connections among members of the same group or network. Other scholars (Paxton, 1999) use different terminologies for similar distinctions, such as Freitag and Traunmüller (2009), who categorize trust into abstract and intimate trust. Meanwhile, some scholars emphasize that the radius of trust depends on an individual's cultural background (Delhey et al., 2011) and initial conditions. Regardless of the different terms to categorize trust in a given situation, it is important to recognize that deep-rooted trust based on personal ties is far different from generalized trust, and more particularly, from trust in strangers (wide trust). Narrow-radius trust, also called in-group trust or trust within those in close social proximity, builds on the in-group/out-group boundary. It may also be an aspect of social network support (i.e., a private good stemming from personal relationships rather than a public good) (Torche and Valenzuela, 2011).

Some authors argue that narrow or in-group trust may not necessarily translate into broader social outcomes (Algan and Cahuc, 2014). However, Alesina et al. (2013) highlight the important economic consequences of family trust due to its problem-solving features, which play an important role in economic development. Moreover, Uslaner (2002) categorizes it as strategic trust because it is based on an individual's actual experience and hence involves an informed assessment of the risk of trusting the other person. Consequently, it reduces asymmetric information and transaction costs, and facilitates transactions, including financial ones, between two parties. Uslaner (2002) further adds that this strategic trust may be based on a range of factors such as intimacy, emotional attachment, knowledge about one another's integrity, or informal control through reputation and sanctions in networks.

In contrast, generalized trust, which is trust in "most people," and wide trust, which is trust in people we do not know or who belong to another group, complete the realm of interpersonal trust. Delhey et al. (2011) assert that although the majority of the 51 countries they examine consider "most people" as those belonging to another group or network, some attach a more in-group connotation while it is ambiguous for others. Hence, generalized trust is not necessarily equivalent to having a wide trust radius.

Some distrust in strangers can be healthy in many circumstances. However, when people are unwilling to cooperate with those they do not know personally, they prevent a great deal of productive social interactions. Moreover, anonymous trust is beneficial for firms because large corporations rely on cooperation among strangers (Fukuyama, 1995). Indeed, La Porta et al. (1997) and Cingano and Pinotti (2012) find trust is positively related to large firms' share of the economy and firm size, respectively.

Several studies stress the lack of compatibility between particularized trust and generalized trust and between particularized trust and wide trust. Fukuyama (1995) suggests that generalized and particularized forms of trust drive each other out. In addition, Uslaner (2002), analyzing the relationship between particularized trust and generalized trust using factor analysis, finds that the two forms of trust belong to distinct factors. Some authors, however, such as Glanville and Paxton (2007) highlight that ingroup trust may not necessarily impede confidence in others. Newton (2001) asserts that different sorts of trust are independent of one another. Freitag and Traunmüller (2009) find that though intimate trust and abstract trust are distinct forms of trust, they are positively correlated, implying that particularized trust enables generalized trust. These studies suggest that it is plausible for individuals to display varying degrees of generalized and particularized trust. Consequently, different combinations of particularized and generalized trust, and particularized trust and wide trust may characterize different societies. Indeed, there may be areas where high in-group or particularized trust may tend to alienate the build-up of generalized trust, out-group trust, and more broadly, trust in strangers, whereas developing all forms of trust may be more plausible in other societies.

\subsection{Trust and Financial Development}


In the social capital literature, trust is a key trait that enables cooperation between people (Coleman, 1990; Putnam, 1993; Uslaner, 2002) and is a critical driver of economic outcomes (Knack and Kneefer, 1997). Arrow (1972) emphasizes its importance in enabling cooperative behavior and in facilitating transactions in the presence of information asymmetry and incomplete contracts. Indeed, trust is crucial for a well-functioning market as financial transactions involve promises of future payment. Individuals conduct transactions with other parties under the presumption that debtors are largely trustworthy; otherwise, consistently resorting to legal institutions as a recourse mechanism in case of nonrepayment would be very costly. Moreover, through norms and sanctions, trust may substitute for formal institutional mechanisms to ensure repayment. Calderón et al. (2002) provide empirical evidence of a positive correlation between trust and financial development, indicating that countries with higher trust levels tend to have more interconnected financial sectors and more efficient credit markets. Algan and Cahuc (2014) and Cline and Williamson (2016) also find similar positive links between trust and financial development.

In the context of emerging and less developed economies, the literature also investigates the role of trust in access to finance, particularly on microfinance. Group lending, which is the dominant lending technique microfinance institutions adopt, rests on the principle of high trust and strong social ties among group members who are jointly responsible for the group loan repayment. Several studies show that the existence of high levels of social capital and trust determines repayment performance (Postelnicu and Hermes, 2018; van Bastelaer and Leathers, 2006).

These bodies of research suggest that trust, regardless of its form, may positively affect financial development outcomes. To the extent that particularized trust facilitates access to informal loans and small group loans, which is the case in microfinance lending, and that it may enhance relationship-based banking, generalized trust and trust in strangers enable cooperative behavior that is vital in bank lending and formal credit markets. Bowles and Gintis (2004) find that parochial networks or groups that are formed based on cultural distinctions between insiders and outsiders, may foster economic development through increased trust. They argue that trust plays a vital role in the enforcement of informal contracts and consequently offsets benefits from trading with outsiders. Further, they argue that such networks solve economic issues within their groups that the market and the state often find difficult to resolve. Cline and Williamson $(2016,2020)$ further confirm this; they show that trust enhances contract efficiency by reducing the demand for contract regulation. In addition, they suggest that trust may be an alternative to formal contract enforcement mechanisms. Moreover, Aghion et al. (2010) and Pinotti (2012) find trust attenuates pressures for government intervention and show a negative relationship between trust and business entry barriers.

As more secured, formal credit and unsecured credit cater to different sets of borrowers, which is characteristic of segmented credit markets, it may be argued that high levels of particularized, generalized trust, and wide trust could result in better financial development outcomes, complementing one another in further developing financial markets.

\subsection{Link between Trust, Fractionalization, and Financial Development}

Social identity theory purports that individuals are more concerned about the welfare of fellow group members or people they share a specific affiliation or identity (i.e., regional, religious, ethnic) with (Tajfel et al., 1971). Antagonism toward others, especially out-group members, deters cooperative behavior, which adversely affects economic and financial development. Indeed, various studies link ethnic fractionalization or fragmentation to lower economic growth and financial development, as well as lower quality of governance (Alesina and La Ferrara, 2005). Coupled with a rational evaluation of another person's trustworthiness (Coleman, 1990; Hardin, 2002) as a basis of trusting others, an 
individual is more likely to trust in or depend on people he/she knows. Further, repeated interactions due to the high frequency one spends with his/her group develops a reputation mechanism, which is vital in conducting business. For example, as Greif (1993) discusses, most traders formed coalitions on the basis of ethnic identity during medieval times in order to exchange information about opportunistic behavior among market agents. Thus, the more ethnically heterogeneous a community is, the more trust becomes crucial, particularly trust in strangers and/or out-group trust, in order to encourage cooperative behavior and facilitate transactions within the community. Trust in others may, hence, be more vital for better financial development outcomes where ethnic fragmentation may be higher.

Further, several authors suggest that ethnic heterogeneity may influence the formation of out-group trust. Dincer (2011) and Putnam (2007) argue that although the conflict hypothesis implies that diversity drives out trust to others and encourages trusting one's own group, contact hypothesis suggests that the more an individual interacts with an "outsider" due to ethnic heterogeneity, the more they trust others. Empirical studies find mixed results. Although Delhey and Newton (2005) and Alesina and La Ferrara (2002) provide evidence supporting the conflict hypothesis, Stolle et al. (2008) finds that the conflict hypothesis only holds if there is lack of contact between groups. Further, Montalvo and Reynal-Querol (2005) purport that diversity does not necessarily lead to lower trust and conflict. To the extent that an ethnically heterogeneous society may either foster in-group or out-group trust, depending on which effect dominates the other, fragmentation that is coupled with out-group trust or to a broader extent, with wide trust, is expected to induce cooperative behavior that is vital for financial development.

\section{The Data}

We consider the 12 NUTS statistical regions of Turkey at the NUTS-1 level for 2004-2017. ${ }^{1,2}$ Although the relatively high level of aggregation at the regional level considerably reduces the number of observations in our study, a lower level of aggregation (NUTS-2) is less accurate, as Boldrin and Canova (2001) and Basile (2008) argue, due to its sometimes artificial nature. Our approach is consistent with previous studies that investigate the role of trust, for instance in Europe, such as Beugelsdijk and Van Schaik (2005), who also consider the NUTS-1 level. The 12 regions in our study are Istanbul, West Marmara, Aegean, East Marmara, Western Anadolu, Mediterranean, Central Anatolia, West Karadeniz, East Karadeniz, Northeastern Anatolia, Mid-Eastern Anatolia, and Southeastern Anatolia.

\subsection{Financial Development Measures}

Financial sector development may be measured in a number of ways (Beck et al., 2007; Čihák et al., 2012). In this study, we use four financial development indicators, which are based on either bank deposits or bank loans. We obtain data from The Banks Association of Turkey (TBB). Specifically, we consider the natural logarithm of regional credit per capita (creditpercapita), the natural logarithm of regional deposits per capita (depositpercapita), regional deposits to regional GDP (deposit-to-income), and regional credit to regional GDP (credit-to-income). We use regional consumer price indices (CPI) to deflate per capita domestic income and other financial indicators into real values. We focus on bank deposits and loans, not only because they represent the main services offered by financial institutions as shown in Beck et al. (2007), but also due to data availability at the regional level since 2004. Most studies focus on cross-country analyses; however, for regional-level analyses, the aim is to reflect the density and depth of each region's financial system. Mitra et al. (2002) use the number of bank branch offices per 1,000 inhabitants, as well as deposits and loans as a percentage change in income as proxy variables.

\footnotetext{
${ }^{1}$ We note that trust data limitations also affect our choice to conduct the study at the NUTS-1 level instead of the more aggregated NUTS-2 level. ${ }^{2}$ NUTS stands for Nomenclature of Territorial Units for Statistics. See http://epp.eurostat.ec.europa.eu
} 
Meanwhile, Ghosh and De (2005) use credit/deposits in national banks, share of tax revenue in net state domestic product (NSDP), and number of post offices per 10,000 people.

\subsection{Trust Measures}

The first step in our empirical study is to identify a reasonable measure of trust at the regional level. Due to the lack of a complete set of statistical data on types of trust within Turkey, our trust measure is from the World Values Survey (WVS) (Inglehart et al., 2014a, 2014b), which is recognized as the reference and possibly the only reliable source for comparisons across regions and countries over time (Guiso et al., 2004; Algan and Cahuc, 2014). The samples are selected using a combination of probabilityproportional-to-size and multistage sampling techniques. Three different types of questions distinguish generalized from particularized or narrow and wide trusts.

To quantify generalized trust, we rely on the respondents' answer to the question "Generally speaking, would you say that most people can be trusted, or that you can't be too careful in dealing with people?" Two candidate answers are: (i) Most people can be trusted, and (ii) You need to be very careful in dealing with people. Our measure, generalizedtrust, is the percentage of people in each region who answered "(i) Most people can be trusted."

The question to assess the level of particularized trust (narrowtrust) is: "Could you tell me whether you trust people you know personally completely, somewhat, not very much or not at all?" Moreover, to measure wide trust or trust in people one has never interacted with (widetrust), we rely on the respondents' answer to the question: "Could you tell me whether you trust people who you meet for the first time completely, somewhat, not very much or not at all?" The corresponding narrow trust and wide trust measures, narrowtrust and widetrust, respectively, are the proportion of people in each region who said they completely or somewhat trust people they know personally and people they meet for the first time.

Although many cross-country and within-country studies use the WVS, some researchers question its appropriateness, such as translation difficulty, question and data inconsistency, and differential response bias. Nevertheless, after comparisons with independent data sources, it is a valid measure of honesty, trust, and trustworthiness. For example, Knack and Keefer (1997) emphasize that such problems do not introduce noise, but rather capture universal interpersonal trust. Uslaner (2002), Bjørnskov (2007), Sapienza et al. (2013) also provide evidence regarding the appropriateness of this measure from different perspectives.

As of 2017, the WVS comprises six waves in Turkey, published in 1990, 1996, 2001, 2007, and 2012. In the 1990, 1996, and 2001 surveys, the respondent's geographical location is not reported. Consequently, we only use information from the 2007 and 2012 WVS (waves 5 and 6) (Inglehart et al., 2014a, 2014b) covering responses from 1,346 and 1,605 individuals, respectively.

We note that the WVS measure of trust changes very slowly over time. For example, Yang and Shen (2010) argue that the trust levels in different provinces of China remain almost unchanged during the past several years. Knack and Keefer (1997) indicate that for 20 market economies with trust levels reported in 1981 and in 1990, the correlation of trust measured at the two dates is as high as 0.91. Uslaner (2002), Bjørnskov (2007), and Tabellini (2008) also report that trust remains almost unchanged within a very long period of time, and such a period can last for as long as half a century. In this study, we use data from the 2007 WVS wave to measure regional trust levels from 2004 to 2010, and we base the regional trust indicator over 2011-2017 from the 2012 WVS wave. 


\subsection{Fractionalization Measure}

To measure ethnic heterogeneity or fractionalization, we use the regional ethnic fractionalization index defined by Alesina and Zhuravskaya (2011). This indicator captures the probability that two randomly selected individuals in a region belong to different ethnic groups. For each region $j=1,2, \ldots 12$, ethnic fractionalization ( fractionalization $_{j}$ ) is calculated as follows:

$$
\text { fractionalization }_{j}=\Sigma_{m=1}^{2} \pi_{j m}\left(1-\pi_{j m}\right)
$$

Where $\pi_{j m}$ is the fraction of ethnic group $m$ (either Turks or Kurds) in region $j$. Higher fractionalization indicates higher ethnic fragmentation and, thus, higher incidence of ethnic tensions and conflicts.

\subsection{Control Variables}

We consider several control variables that are commonly used in the literature. We obtain information from the National Institute of Statistics (TUIK). The first is regional GDP growth, a measure of economic development. Because of possible reverse causality between economic growth and financial development (Peia and Roszbach, 2015), we use initial regional GDP growth, calculated as average regional GDP growth (initialGDPgrowth) before our study period (2000-2004). The second variable indicates the dominant economic sector in the region based on its share of regional GDP. We define a binary variable, sector-services, which is equal to one if the services sector is the dominant sector (or has the highest share in regional GDP) in their region, and zero otherwise. We also include a dummy variable, dummy Istanbul, indicating the country's business and financial center. We note that most financial institutions in Turkey are in Istanbul. We also control for time fixed effects by introducing year dummy variables.

Table 1 shows the summary statistics, and table 2 reports the correlation matrix of the variables in our estimations.

[Insert Tables 1 and 2]

\subsection{Descriptive Evidence: Stylized Facts and Local Context}

The WVS results in 2012 reveal that in terms of generalized trust, Turkey is a relatively distrustful society, with only $11.6 \%$ of respondents agreeing with the statement, "Most people can be trusted." The level of interpersonal trust in Turkey, for instance, is far below the OECD average in 2008 (59\% of people expressing a high level of trust in others, on average), with Turkey ranking $29^{\text {th }}$ out of the $30-$ member states. Regardless, Turkey is the $19^{\text {th }}$ largest economy in the world in terms of nominal GDP, as reported in the IMF World Economic Outlook Database in 2019, with a financial development index of 0.537 and a financial markets index of 0.589 , ranking $37^{\text {th }}$ and $27^{\text {th }}$ out of 183 economies, respectively, in the 2013 rankings of financial development (Svirydzenka, 2016).

Regional differences in economic activity and trust are prevalent in Turkey. Kayaoglu (2017) purports that regional variations in education levels and income inequality explain trust differences. Moreover, regional trust variations are also related to differences in regional financial development. Figures 1a and 2a show generalized trust levels in 2007 and 2012, respectively, and figures $1 \mathrm{~b}$ and $2 \mathrm{~b}$ show average regional deposits per capita between 2004 and 2010, as well as between 2011 and 2017, respectively. Generalized trust, measured as the percentage of respondents who agree to the statement, "Most people can be trusted," is highest in the Mediterranean and East Marmara regions, and it is weakest in 
Southeastern Anatolia and West Marmara. Moreover, we observe that financial development is relatively high in regions where generalized trust is also relatively high. In addition, we observe increasing generalized trust and financial development over time. For example, in Istanbul, we note that in 2007 when merely $4 \%$ of the population agrees that most people can be trusted, credit per capita is 1.990 thousand Turkish Lira (TL) and deposits per capita are 3.840 thousand TL. In 2012, the level of generalized trust increases to $17 \%$, while credit and deposits per capita increase by more than four times to 17.27 thousand TL and 19.81 thousand TL, respectively. Moreover, we observe regional trust and financial development variations. Although eastern regions' average trust levels are $6.9 \%$ to $10.4 \%$, from the results of the WVS waves 5 and 6, respectively, and deposits per capita are less than 2.4 thousand TL, central and western regional trust levels are around 14\%, and deposits per capita are 12 thousand TL.

[Insert Figures 1a, 1b, 2a \& 2b]

Regional inequalities in economic development are also present across Turkey. Provinces in Eastern and Southeastern Anatolia, the eastern Black Sea region, certain parts of Central Anatolia, and even some parts of western Anatolia and the Mediterranean are relatively less developed than others. Several factors explain such variations. First, Srikantan (1973) emphasizes differences in geographic features across regions. Second, ethnic polarization and demographic shocks between 1913 and 1927 due to the Armenian and Muslim conflict resulted in a population decline in eastern Turkey of around 30\% (Asik et al., 2020). Moreover, Kurds, who are the largest ethnic group after Turks, mostly live in eastern Turkey. Eastern regions are, hence, more ethnically fragmented. In addition, they are relatively less developed compared with other regions, such as those in the west. This is consistent with studies indicating that ethnic fractionalization is linked to low economic growth (Alesina and La Ferrara, 2005). Thus, Asik et al. (2020) also find that demographic changes and ethnic fragmentation are important drivers of regional inequalities in Turkey. The migration of younger and generally more educated people from rural to urban areas and from lower-income to higher-income regions also keeps education levels relatively low in the eastern regions. In contrast, the more educated segments of the population are concentrated in the urban areas, especially in the largest metropolitan areas (Tansel and Güngör, 1997). Last, government policies that tend to prioritize some regions and the quality of local governance can also explain regional inequalities. Although the national government implemented regional development programs to improve social welfare and the economy in poor regions, the absence of a shared vision among the planners, the intended beneficiaries, and the local communities impaired the effectiveness of such programs (Mutlu 1996; Carkoglu and Eder, 2005).

\section{Empirical Methodology and Results}

\subsection{Baseline Specification: Instrumental Variable Regression}

There is no consensus in the literature regarding causality between trust and economic performance. On one hand, Uslaner (2008) and Algan and Cahuc (2010) indicate that the causality runs from social capital to economic growth because social capital exhibits a time-invariant heritable component that is passed on from generation to generation. ${ }^{3}$ On the other hand, some authors argue that trust may not be stable over time but is a product of an individual's environment and experiences; consequently, economic performance is likely to affect trust. For example, Dinesen (2012) finds that immigrants adjust their trust levels to those of the natives in the destination country. In addition, Chan (2007) argues that increases in trade openness may increase trust as long as income inequality is low.

\footnotetext{
${ }^{3}$ Trust is a crucial component of social capital (Putnam et al., 1993). Moreover, Bjørnskov (2006) finds trust is the sole social capital component that explains governance and life satisfaction. Thus, discussion of the relationship between social capital and economic performance is relevant in understanding the link between trust and financial development.
} 
Considering plausible endogeneity concerns with regard to our trust variables, mainly generalized trust and wide trust due to a possibly reverse causal relationship between trust and financial development and measurement error, we use the instrumental variable (IV) regression method. We mainly utilize the average value of neighboring regions' trust measures and the region's number of foundations as instruments for generalized trust and wide trust. ${ }^{4}$ We argue that neighboring regions' trust levels are correlated to a region's level of trust, which may be attributed to geographical proximity that increases the incidence of repeated economic and social interactions in the population. In addition, proximity facilitates mobility and migration between regions, thus affecting a region's trust levels. Moreover, the literature documents the impact of common horizontal networks such as neighborhoods, civic associations, schools, and churches in reinforcing the social capital environment (Li et al., 2018). To test the validity of our instruments and establish that our IV estimators are consistent, we perform the Kleibergen-Paap rk LM test and the Hansen-J test. We also execute the C-statistic test of exogeneity to check whether wide trust and generalized trust are indeed endogenous.

We estimate the following baseline specifications (equations 1 and 2):

$$
\begin{aligned}
& \text { FinDev }_{i t}=\beta_{0}+\beta_{1} \text { generalizedtrust }_{i t}+\Lambda \mathrm{X}+\varepsilon_{i t} \\
& \text { FinDev }_{i t}=\beta_{0}+\beta_{1} \text { generalizedtrust }_{i t}+\beta_{2} \text { narrowtrust }_{i t}+\beta_{3} \text { wi det rust }_{i t}+\Lambda \mathrm{X}+\varepsilon_{i t}
\end{aligned}
$$

Where equation 1 is a nested model, considering only generalized trust (generalizedtrust), and equation 2 is a broader model, which introduces the two other forms of trust: narrow (narrowtrust) and wide (widetrust). FinDev represents the four measures covering different financial development aspects, creditpercapita, depositpercapita, credit-to-income, and deposit-to-income. $\mathrm{X}$ is a vector of regionspecific, time-variant, and time-invariant variables that affect regional financial development, such as GDP growth (initialGDP growth), which is a dummy variable indicating whether the services sector is dominant in the region (sector-services), a dummy variable indicating the country's financial center (dummy Istanbul), and one indicating its regional fractionalization (fractionalization).

We note that positive and significant coefficient estimates of trust measures indicate significantly positive relationships between trust (and the different radii/forms of trust) and financial development. Moreover, the estimation results from eq. 2 provide a better understanding of the dynamics of different forms of trust and financial development, considering trust measures at the opposite ends of the spectrum (narrow and wide).

\subsection{Links between Different Radii of Trust and Financial Development}

We also investigate whether specific combinations of trust, by interacting our various trust measures, are associated with better financial development outcomes. More specifically, we examine the marginal effect of increasing generalized trust and wide trust in enabling more extensive use of financial services at varying levels of narrow trust. We purport that high generalized trust or wide trust in a region where trust in people personally known is very high increases per capita deposits and credit levels. We thus investigate whether generalized trust and narrow trust, and wide trust and narrow trust, are complements in improving financial development outcomes.

\footnotetext{
${ }^{4}$ These refer to the new foundations, which independent courts establish after the creation of the Republic of Turkey in 1923. They are distinct from old foundations formed during the Ottoman Empire. The new foundations carry out activities in areas such as education, culture, health, and science. We obtain data on the number of foundations by region from the T.R. Directorate General of Foundations.
} 
We hence, estimate equations $3 \mathrm{a}$ and $3 \mathrm{~b}$.

$$
\begin{aligned}
& \text { FinDev }_{i t}=\beta_{0}+\beta_{1} \text { generalizedtrust }_{i t}+\beta_{2} \text { narrowtrust }_{i t}+\beta_{3} \text { wi det rust }_{i t}+
\end{aligned}
$$

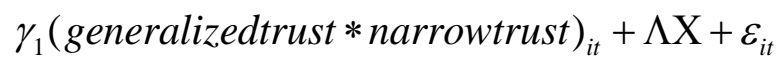

$$
\begin{aligned}
& \text { FinDev }_{i t}=\beta_{0}+\beta_{1} \text { generalizedtrust }_{i t}+\beta_{2} \text { narrowtrust }_{i t}+\beta_{3}{\text { wi det } \text { rust }_{i t}+}+ \\
& \gamma_{2}\left(\text { widetrust }^{*} \text { narrowtrust }\right)_{i t}+\Lambda \mathrm{X}+\varepsilon_{i t}
\end{aligned}
$$

Where generalizedtrust*narrowtrust and widetrust*narrowtrust are the interaction terms between generalized trust and narrow trust, and between wide trust and narrow trust, respectively. We calculate the marginal effect of generalized trust and wide trust on financial development outcomes for different percentile values of narrow trust $\left(\beta_{1}+\gamma_{1} *\right.$ narrowtrust $\left._{i t}\right),\left(\beta_{1}+\gamma_{2} *\right.$ narrowtrust $\left._{i t}\right)$. A positive and significant coefficient indicates a complementary impact of wide trust and narrow trust, as well as generalized trust and narrow trust, on financial development outcomes.

\subsection{Exploring the Link between Trust and Fractionalization}

Alesina and Giulano (2015) assert that trust travels less effectively across groups than among group members. We analyze whether the beneficial effects of trust, in terms of higher use of credit and deposit services, depend on ethnic group heterogeneity. We expect a stronger link between generalized trust or wide trust and financial development outcomes in areas where fractionalization is high or in ethnically heterogeneous regions. This is because trust in more fragmented areas, in general, is low (Alesina and La Ferrara, 2000, 2002), especially for “out-group" members (Guiso et al., 2009). Similar observations are in the experimental literature, where participants tend to cooperate more with in-group members than others (Chen and Li, 2009). Moreover, in more ethnically homogeneous regions, we expect high trust levels, in general, to lead to more extensive use of financial services. We thus test whether a specific form of trust achieves better financial development outcomes depending on how distinctions are deeply rooted between ethnic groups. Players of trust games from opposing ethnic affiliations and cultural groups often show mistrust of the other group (Fershtman and Gneezy, 2001) and tend to reciprocate trust accorded to them (Bornhorst et al., 2010).

We hence estimate the following equations (equations $4 \mathrm{a}, 4 \mathrm{~b}$ and $4 \mathrm{c}$ ):

$$
\begin{aligned}
& \text { FinDev }_{i t}=\beta_{0}+\beta_{1} \text { generalizedtrust }_{i t}+\beta_{2} \text { narrowtrust }_{i t}+\beta_{3}{\text { wi det } \text { rust }_{i t}+} \\
& \beta_{4} \text { fractionalization }_{i t}+\phi_{1}\left(\text { generalizedtrust }^{*} \text { fractionalization }_{i t}+\Lambda \mathrm{Z}+\varepsilon_{i t}\right.
\end{aligned}
$$

$$
\begin{aligned}
& \text { FinDev }_{i t}=\beta_{0}+\beta_{1} \text { generalizedtrust }_{i t}+\beta_{2} \text { narrowtrust }_{i t}+\beta_{3}{\text { wi det } \text { rust }_{i t}+}+ \\
& \beta_{4} \text { fractionalization }_{i t}+\phi_{2}\left(\text { narrowtrust }^{*} \text { fractionalization }_{i t}+\Lambda \mathrm{Z}+\varepsilon_{i t}\right.
\end{aligned}
$$

FinDev $_{i t}=\beta_{0}+\beta_{1}$ generalizedtrust $_{i t}+\beta_{2}$ narrowtrust $_{i t}+\beta_{3}$ wi det rust $_{i t}+$

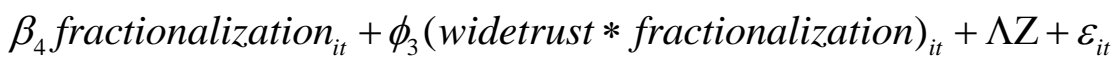

Where generalizedtrust*fractionalization, narrowtrust*fractionalization, and widetrust ${ }^{*}$ fractionalization are the interaction terms between generalized trust and fractionalization, between narrow trust and fractionalization, and between wide trust and fractionalization, respectively. We 
calculate the marginal effects of generalized trust, narrow trust, and wide trust on financial development outcomes for different percentile values of the regional fractionalization measure derived from Alesina and Zhuravskaya (2011) - $\beta_{1}+\phi_{1} *$ fractionalization , $\beta_{2}+\phi_{2} *$ fractionalization, $\beta_{3}+\phi_{3} *$ fractionalization.

\subsection{Empirical Results}

\subsubsection{Results: Baseline Specification}

We present the IV estimation results of equations 1 and 2 in tables $3 \mathrm{a}$ and $3 \mathrm{~b}$, respectively, examining the relationship between generalized trust (generalizedtrust) and the two radii of trust at the opposing ends of the spectrum (narrowtrust and widetrust) and financial development. We reject the null hypothesis of exogeneity of the variables generalizedtrust in equation 1 and generalizedtrust and widetrust in equation 2 as indicated by the $\mathrm{C}$-statistic test of exogeneity. Moreover, both the Kleibergen Paap rk LM and Hansen J statistics confirm the validity of our instruments.

\section{[Insert Tables 3a and 3b]}

In table 3a, we find a positive and significant link between generalized trust and financial development. This indicates that individuals in regions with relatively higher generalized trust tend to use credit and deposit services more extensively. We obtain such findings after controlling for population (creditpercapita and depositpercapita) and average income (credit-to-income and deposit-to-income). For equation 2, controlling for specific trust measures (narrow and wide trust), our findings show that, in general, more trust-intensive regions with high wide trust are relatively more financially developed. We note, however, that the positive relationship between generalized trust and financial development disappears after controlling for the two radii of trust at the opposite ends of the spectrum (narrow trust and wide trust). This possibly indicates that generalized trust in equation 1 partially captures the impact of wide trust on financial development. Overall, our findings suggest that an increase in wide trust, which consists of trust in strangers, enables cooperation among different economic agents in society, hence improving financial development outcomes. Moreover, our results indicate that more fragmented regions tend to be less financially developed. Such findings are consistent with scholars who show that fractionalized communities tend to experience political and economic challenges, leading to low-quality government and hence poor provision of public goods and services (Alesina and Ferrara, 2005). In terms of our control variables, we find that the region where the financial and economic capital city is located, Istanbul, is more financially developed than other regions.

\subsubsection{Results: Interaction between Different Radii of Trust and Financial Development Outcomes}

Table $4 \mathrm{a}$ presents the estimation results of equations $3 \mathrm{a}$ and $3 \mathrm{~b}$. The aim is to investigate whether there are complementary effects between generalized trust and narrow trust, and between wide trust and narrow trust. We show the computed marginal effects of generalized trust and wide trust at different percentile levels (low, median, and high) for narrow trust in tables $4 \mathrm{~b}$ and $4 \mathrm{c}$.

[Insert Tables 4a, 4b \& 4c]

Our findings reveal a significant impact of the interaction between generalized trust and narrow trust on financial development. An increase in generalized trust is most significant in regions exhibiting extremely high narrow trust. These results also suggest that particularized trust is important for financial development as long as generalized trust is also high. In contrast, we find the interaction effect between 
wide trust and narrow trust is less striking, only showing a significantly positive impact on credit-toGDP and deposit-to-GDP ratios. These findings indicate that the role of generalized trust in improving financial development depends on the degree of specific (in-group) trust. The benefits from generalized trust are larger in areas where the formation of social networks outside the bounds of familial and familiar ties is less likely, which is the case in regions where narrow trust is high. This suggests that positive complementary effects occur when improving both generalized and particularized trust for financial development.

\subsubsection{Results: Interaction between the Different Radii of Trust and Ethnic Heterogeneity, and Financial Development Outcomes}

We present in tables $5 \mathrm{a}$ and $5 \mathrm{~b}$ the regression results and the calculated marginal effect of generalized trust on financial development at varying degrees of fractionalization using regional data.

[Insert Tables 5a \& 5b]

Our findings show that increasing generalized trust leads to better financial development outcomes in less fragmented or more ethnically homogeneous regions than in highly fractionalized societies. Although we find that generalized trust has a positive impact on financial development even in regions with very high ethnic fractionalization, this beneficial effect is lower than in more ethnically homogeneous regions. Moreover, we find that an increase in generalized trust does not increase creditto-GDP ratios in more ethnically fragmented regions. These results indicate that the positive impact of increasing generalized trust is less binding in fragmented societies, where divergence from norms and values could ultimately hinder the formation of trust. Moreover, we note that the local environment may affect individual responses to the generalized trust survey question. To better understand how ethnic heterogeneity or fractionalization affects the relationship between trust and financial development, we look into the interaction between the two radii of trust at each end of the spectrum (narrow trust and wide trust) and fractionalization. We report the estimation results of equations $4 \mathrm{~b}$ and $4 \mathrm{c}$ in table $6 \mathrm{a}$.

[Insert Table 6a]

We find contrasting signs of the interaction terms between narrow trust and fractionalization (narrowtrust*fractionalization) and between wide trust and fractionalization (widetrust*fractionalization). On one hand, we find that an increase in narrow trust exacerbates the pervasive effects of fractionalization on financial development. Indeed, an increase in narrow trust leads to lower financial development outcomes in more ethnically fragmented regions. On the other hand, our findings show that, in highly fractionalized regions, wide trust has positive and significant mitigating effects. The marginal effects of narrow and wide trust, at varying levels of ethnic fractionalization (shown in tables $6 \mathrm{~b}$ and $6 \mathrm{c}$ ), confirm our results. Indeed, reinforcing narrow trust in highly fractionalized regions tends to harm financial development. The negative marginal effects of narrow trust in highly fragmented regions support this. In contrast, we find that the marginal benefit from increasing wide trust, or trust in people one meets for the first time, is strongest in regions with high ethnic heterogeneity. As mentioned, ethnic heterogeneity or diversity tends to foster trust, particularly toward in-group members (Alesina and Giuliano, 2015). Increasing wide trust, hence, could enhance cooperation in these regions, which is vital for financial development. Moreover, our results support studies finding that strong interpersonal trust is important in developing credit markets where institutional quality is poor or where contract enforcement is weak at the country level (Knack and Keefer, 1997; Guiso et al., 2004), which is more likely the case in highly fractionalized societies where quality of government or provision of public goods and services is poor (Alesina and La Ferrara, 2005).

[Insert Tables $6 \mathrm{~b} \& 6 \mathrm{c}]$ 


\section{Robustness Checks}

We perform several robustness checks by exploring further issues. First, we investigate whether regional variations in the trust-in-banks indicator affect financial development outcomes. Second, we analyze how trust affects the extent of financial intermediation more specifically by using the credit-to-deposit ratio. As in our main empirical specifications, we use the instrumental variable regression method. We present the results of our estimations in the appendix.

\subsection{Specific Trust in Banks and Financial Development}

Fungáčová et al. (2019) discuss the importance of trust in banks in fostering economic growth via financial inclusion and financial stability. We thus examine the link between specific trust in banks and financial development. We note, however, that measurement errors may plague trust in institutions due to cultural biases and different perceptions of the efficiency of these institutions (Alesina and Giuliano, 2015). Consequently, we analyze the relationship during a period where GDP growth is relatively stable in Turkey (more than \$10,000 GDP per capita, between 2011 and 2017) and interpret our results with caution.

To measure trust in banks, we construct a dummy variable, banktrust, which is equal to one if WVS survey respondents said they had a great deal of confidence or quite a lot of confidence in banks. We note, however, that this question was only available from the sixth wave of the WVS in Turkey, more precisely from 2012, and thus, we only estimate our model using the 2011-2017 study period. We note that around $56 \%$ of the respondents said they did not have very much confidence or had no confidence at all in banks. We present the estimation results of equation $2^{5}$ in appendix A. We use average values of the generalized trust, bank trust, and wide trust indicators of neighboring regions as instruments for generalized trust and bank trust. The Hansen $\mathrm{J}$ and Kleibergen-Paap rk LM tests of overidentification and underidentification, respectively, both indicate that our instruments are valid. The C-statistic test of exogeneity indicates that bank trust and generalized trust are indeed endogenous. Our findings indicate that regions where bank trust is high also have more developed financial markets. We also note that narrow trust is positively linked to financial development during the 2011-2017 period. Meanwhile, generalized trust is not positively associated with better financial development outcomes, consistent with our baseline results.

\section{[Insert Appendix A]}

\subsection{Trust and Credit Availability from Stable Funds Using the Credit-to-Deposit Ratio}

We examine how trust relates to credit backed by stable funds or to the potential for credit intermediation. We use the ratio of credit to total deposits (credit_over_deposit) to measure credit intermediation potential. A number of studies use this measure (Disalvo and Johnston, 2017). Higher total credit in relation to total deposits (credit_over_deposit $>1$ ) indicates higher reliance on nondeposit (relatively unstable) funding sources to finance lending activities or strong credit demand that deposits cannot match. We note that the average regional credit-to-deposit ratio has been increasing in Turkey from 0.51 in 2004 to 1.45 in 2017, with an average of 1.08 during our study period. This indicates that bank assets, particularly loans, grow at a higher rate than do key stable funding sources such as deposits. We hence,

\footnotetext{
${ }^{5}$ We note a very high correlation between wide trust and trust in banks; thus, we only include trust in banks in our estimation.
} 
analyze the role trust plays in increasing stable funding to fund loans. More particularly, we investigate whether regions that have higher trust levels have higher credit intermediation potential and, thus, have lower credit_over_deposit values. In, other words, do these regions have funds (deposits) stable enough to finance personal and firm credit? Can the public back increasing credit demand by increasing deposits? In terms of the interpretation of the coefficients, a negative coefficient of the trust variables (generalizedtrust, narrowtrust, and widetrust) implies a positive link between trust and the potential for credit intermediation. We present our estimation results in appendix B.

\section{[Insert Appendix B]}

The findings in table B1 indicate that regions with stronger generalized and narrow trust have higher credit intermediation potential or a larger deposit base to fund lending activities. Moreover, in terms of the interaction between generalized trust and narrow trust, and between wide trust and narrow trust, our results indicate that higher generalized trust and higher wide trust are associated with larger available credit supply from stable sources but only in regions with median to high levels of narrow trust (see table B2). This further confirms our previous findings indicating that generalized trust and narrow trust might be complements. We also find better credit intermediation potential in regions with higher wide trust, given high particularized or narrow trust.

Assessing the role trust plays in credit intermediation given varying degrees of regional ethnic fractionalization, our results in table B3 show a significantly positive relationship between all trust measures (generalized, narrow, and wide) and credit intermediation (lower credit-to-deposit ratio) in regions where fractionalization is low. Moreover, we find that although generalized trust increases credit intermediation, albeit to a lower degree where ethnic fractionalization is high, our findings indicate that an increase in narrow trust in these regions tends to diminish credit intermediation potential. This indicates that ethnically fragmented regions characterized by high narrow trust levels have higher credit demand compared to available stable funds such as deposits. Moreover, in terms of the interaction effects between wide trust and fractionalization, our results indicate that regions with relatively high wide trust levels have more stable funds to finance lending activities, but only in areas with low to median ethnic fractionalization. In regions where ethnic fragmentation is high, an increase in wide trust increases credit more than deposits.

\section{Conclusion}

The principal objective of this paper is to analyze the link between trust and financial development by considering two important dimensions. First, by examining three radii or forms of trust (generalized, narrow, and wide), we investigate whether specific combinations of trust result in better financial development outcomes. Second, we study whether regional ethnic heterogeneity affects the mechanism by which trust affects financial development. Our aim is, hence, to determine which types of trust are vital for financial development in highly fractionalized or fragmented societies and whether they are different from what may be considered crucial in more ethnically homogeneous societies.

Our findings indicate that trust, particularly wide trust, is positively associated with the level of financial development. Wide trust encourages cooperative behavior among economic agents, especially in the intermediation process where the lender/saver and borrower do not know each other. Moreover, our results show that increasing generalized trust improves financial development where narrow trust is high, thus highlighting that generalized and narrow trust complement each other. Further, we find wide trust plays a more important role for financial development in fractionalized societies, but generalized trust is 
more crucial in less ethnically heterogeneous communities. Our results also indicate the importance of trust, notably generalized trust, in increasing stable funds such as deposits to fund loans. On the whole, our analyses show that trust is a crucial element in achieving financial development, particularly by increasing the use of formal credit and deposit services that are essential to achieving small-enterprise growth and enabling consumption smoothing. Our findings also highlight that although trust matters for financial development, identifying which sorts of trust support financial development is more crucial. Moreover, our results suggest that increasing trust in individuals we do not personally know goes hand in hand with curbing out-group antagonism, which often enables ethnic heterogeneity's adverse effects on economic outcomes. Overall, our findings imply that establishing an environment that is conducive to cooperation, by increasing trust, is important for financial development. 


\section{References}

Aghion, P., Algan, Y., Cahuc, P., Shleifer, A. (2010). Regulation and Distrust. Quarterly Journal of Economics, 125, 1015-1049.

Alesina, A., Baqir, R., Easterly, W. (1999). Public Goods and Ethnic Divisions. Quarterly Journal of Economics, 114(4), 1243-1284.

Alesina, A., Giuliano, P. (2015). Culture and institutions. Journal of Economic Literature, 53(4):898944.

Alesina, A., Giuliano, P., Nunn, N. (2013). On the origins of gender roles: Women and the plough. The Quarterly Journal of Economics, 128(2):469-530.

Alesina, A., La Ferrara, E. (2000). Participation in heterogeneous communities. The Quarterly Journal of Economics, 115(3):847-904.

Alesina, A., La Ferrara, E. (2002). Who trusts others? Journal of Public Economics, 85(2):207-234.

Alesina, A., La Ferrara, E. (2005). Ethnic diversity and economic performance. Journal of Economic Literature, 43(3):762-800.

Alesina, A., Zhuravskaya, E. (2011). Inherited trust and growth. American Economic Review, 100, 20602092.

Algan, Y., Cahuc, P. (2010). Trust, growth, and well-being: New evidence and policy implications. In Handbook of Economic Growth, 2:49-120. Elsevier.

Algan, Y., Cahuc, P. (2014). Trust, growth, and well-being: New evidence and policy implications. In Handbook of Economic Growth, 2:49-120. Elsevier.

Arrow, K. J. (1972). Economic welfare and the allocation of resources for invention. In Readings in Industrial Economics, pages 219-236. Springer.

Asik, G., Karakoc, U., Pamuk, S. (2020). Regional Inequalities and the West-East Divide in Turkey Since 1880. CEPR Discussion Paper No. DP15304.

Basile, R. (2008). Regional economic growth in Europe: A semiparametric spatial dependence approach. Papers in Regional Science, 87(4):527-544.

Beck, T., Demirgüç-Kunt, A., Martinez-Peria, M.S. (2007). Reaching out: Access to and use of banking services across countries. Journal of Financial Economics, 85(1):234-266.

Beugelsdijk, S., Van Schaik, T. (2005). Social capital and growth in European regions: An empirical test. European Journal of Political Economy, 21(2):301-324.

Bjørnskov, C., Méon, P.G. (2015). The Productivity of Trust. World Development, 70, 317-331.

Bjørnskov, C. (2006). The multiple facets of social capital. European Journal of Political Economy, 22, $22-40$.

Bjørnskov, C. (2007). Determinants of generalized trust: A cross-country comparison. Public Choice, 130(1-2):1-21.

Boldrin, M., Canova, F. (2001). Inequality and convergence in Europe's regions: Reconsidering European Regional Policies. Economic Policy, 16(32):206-253.

Bornhorst, F., Ichino, A., Kirchkamp, O., Schlag, K. H., Winter, E. (2010). Similarities and differences when building trust: the role of cultures. Experimental Economics, 13(3):260-283.

Bowles, S., Gintis, H. (2004). Persistent parochialism: Trust and exclusion in ethnic networks. Journal of Economic Behavior and Organization, 55: 1-53.

Braesemann, F., Stephany, F. (2021). Between bonds and bridges: Evidence from a survey on trust in groups. Social Indicators Research, 153: 111-128.

Calderón, C., Chong, A., Galindo, A. (2002). Development and efficiency of the financial sector and links with trust: Cross-country evidence. Economic Development and Cultural Change, 51(1):189204.

Carkoglu, A., Eder, M., Kirisci, K. (2005). The political economy of regional cooperation in the Middle East, volume 3. Routledge. 
Chan, K. (2007). Trade, social values, and the generalized trust. Southern Economic Journal, 73, 733753.

Chen, Y., Li, S. X. (2009). Group identity and social preferences. American Economic Review, 99(1):431-57.

Čihák, M., Demirgüç-Kunt, A., Feyen, E., Levine, R. (2012). Benchmarking Financial Development around the World. World Bank Policy Research Working Paper 6175, August 2012.

Cingano, F., Pinotti, P. (2012). Trust, firm organization and the structure of production. Technical Report 2012-133, Carlo F. Dondena Centre for Research on Social Dynamics.

Cline, B. N., Williamson, C. R. (2016). Trust and the regulation of corporate self-dealing. Journal of Corporate Finance, 41:572-590.

Cline, B.N., Williamson, C.R. (2020). Trust, regulation, and contracting institutions. European Financial Management, pp.1-37. DOI: 10.111. /eufm.12253

Coleman, J. S. (1990). Foundations of social theory. Harvard University Press.

Corradini, C., 2020. Social trust and new firm formation: A regional perspective. Small Business Economics, pp.1-16.

Delhey, J., and K. Newton. (2005). Predicting cross-national levels of social trust: Global pattern of Nordic exceoptionalism? European Sociological Review, 21, 2005, 311-27.

Delhey, J., Newton, K., Welzel, C. (2011). How general is trust in "most people"? Solving the radius of trust problem. American Sociological Review, 76(5):786-807.

Dincer, O. C. (2011). Ethnic diversity and trust. Contemporary Economic Policy, 29(2):284-293.

Dinesen, P.T. (2012). Does generalized distrust travel? Examining the impact of cultural heritage and destination country environment on trust of immigrants. Political Psychology, 33, 495-511.

DiSalvo, J., Johnston, R. (2017). The rise in loan-to-deposit ratios: Is 80 the new 60? Economic Insights, 2(3):18-23.

Fershtman, C., Gneezy, U. (2001). Discrimination in a segmented society: An experimental approach. The Quarterly Journal of Economics, 116(1), 351-377.

Freitag, M., Traunmüller, R. (2009). Spheres of trust: An empirical analysis of the foundations of particularized angeneralised trust. European Journal of Political Research, 48: 782-803.

Fukuyama, F. (1995). Trust: The social virtues and the creation of prosperity. London: Hamish Hamilton.

Fungáčová, Z., Hasan, I., Weill, L. (2019). Trust in banks. Journal of Economic Behavior \& Organization, 157:452-476.

Ghosh, B., De, P. (2005). Investigating the linkage between infrastructure and regional development in India: Era of planning to globalisation. Journal of Asian Economics, 15(6):1023-1050.

Glanville, J., Paxton, P. (2007). How do we learn to trust? A confirmatory tetrad analysis of the sources of generalized trust. Social Psychology Quarterly, 70: 230-242.

Greif, A. (1993). Contract enforceability and economic institutions in early trade: The Maghribi traders ' coalition. American Economic Review, 83(3): 525-548.

Guiso, L., Sapienza, P., Zingales, L. (2004). The role of social capital in financial development. American Economic Review, 94(3):526-556.

Guiso, L., Sapienza, P., Zingales, L. (2008). Trusting the stock market. The Journal of Finance, 63(6):2557-2600.

Guiso, L., Sapienza, P., Zingales, L. (2009). Cultural biases in economic exchange? The Quarterly Journal of Economics, 124(3):1095-1131.

Hardin, R. (2002). Trust and Trustworthiness. Russell Sage Foundation Series on Trust, Russell Sage Foundation. 2002.

Inglehart, R., C. Haerpfer, A. Moreno, C. Welzel, K. Kizilova, J. Diez-Medrano, M. Lagos, P. Norris, E. Ponarin \& B. Puranen et al. (eds.). (2014a). World Values Survey: Round Five - Country-Pooled Datafile 2005-2008. Madrid: JD Systems Institute. 
Inglehart, R., C. Haerpfer, A. Moreno, C. Welzel, K. Kizilova, J. Diez-Medrano, M. Lagos, P. Norris, E. Ponarin \& B. Puranen et al. (eds.). (2014b). World Values Survey: Round Six - Country-Pooled Datafile 2010-2014. Madrid: JD Systems Institute.

Jiang, D., Lim, S. S. (2018). Trust and household debt. Review of Finance, 22(2):783-812.

Kayaoglu, A. (2017). Hometown associations, urban-to-rural collective remittances and rural development in Turkey. Remittances Review, 2(2):121-136.

Knack, S., Keefer, P. (1997). Does social capital have an economic payoff? A cross-country investigation. The Quarterly Journal of Economics, 112(4):1251-1288.

La Porta, R., Lopez-de Silanes, F., Shleifer, A., Vishny, R. W. (1997). Trust in large organizations. American Economic Review Paper and Proceedings, 87: 333-338.

Li, P., Tang, L., Jaggi, B. (2018). Social capital and the municipal bond market. Journal of Business Ethics, 153, 479-501.

Mitra, A., Varoudakis, A., Veganzones-Varoudakis, M.-A. (2002). Productivity and technical efficiency in Indian states 'manufacturing: The role of infrastructure. Economic Development and Cultural Change, 50(2):395-426.

Montalvo, J., Reynal-Querol, M. (2005). Ethnic diversity and economic development. Journal of Economic Development, 76, 2005a, 293-323.

Mutlu, S. (1996). Ethnic Kurds in Turkey: A demographic study. International Journal of Middle East Studies, 28(4):517-541.

Newton, K. (2001). Social Trust and Political Disaffection: Social Capital and Democracy. Par presented at the EURESCO Conference on Social Capital: Interdisciplinary Perspectives, Exeter, United Kingdom.

Ng, A., Ibrahim, M. H., Mirakhor, A. (2016). Does trust contribute to stock market development? Economic Modelling, 52:239-250.

Paxton, P. (1999). Is social capital declining in the United States? A multiple indicator assessment. American Journal of Sociology, 105(1):88-127.

Peia, O., Roszbach, K. 2015. Finance and growth: Time series evidence on causality. Journal of Financial Stability, 19(C), 105-118.

Pevzner, M., Xie, F., Xin, X. (2015). When firms talk, do investors listen? The role of trust in stock market reactions to corporate earnings announcements. Journal of Financial Economics, 117(1):190223.

Pinotti, P. (2012). Trust, regulation and market failures. Review of Economics and Statistics, 94(3): 650658.

Postelnicu, L., Hermes, N. (2018). Microfinance performance and social capital: A cross-country analysis. Journal of Business Ethics, 153(2):427-445.

Putnam, R. D. (1993). What makes democracy work? National Civic Review, 82(2):101-107.

Putnam, R. D. (2000). Bowling Alone: The Collapse and Revival of American Community. New York: Simon \& Schuster.

Putnam, R.D. (2007). E pluribus unum: Diversity and community in the twenty-first century. Scandinavian Political Studies, 30, 2007, 137-74.

Sangnier, M. (2013). Does trust favor macroeconomic stability? Journal of Comparative Economics, 41(3), 653-668.

Sapienza, P., Toldra, A. and Zingales, L. (2013). Understanding trust. The Economic Journal, 123(573): 1313-1332.

Srikantan, K. (1973). Regional and rural-urban socio-demographic differences in turkey. Middle East Journal, 27(3):275-300.

Stolle, D., Stuart, S., Johnston, R. (2008). When does diversity erode trust? Neighbourhood diversity, interpersonal trust, and the mediating effect of social interactions. Political Studies, 55, 57-75. 
Svirydzenka, K. (2016). Introducing a New Broad-based Index of Financial Development. IMF Working Paper, 16/5.

Tabellini, G. (2008). Institutions and culture: Presidential address. Journal of the European Economic Association, 6(2-3):255-294.

Tajfel, H., Billig, M. G., Bundy, R.P., Flament, C. (1971). Social categorization and intergroup behaviour. European Journal of Social Psychology, Vol. 1(2), 149-178.

Tansel, A., Güngör, N. D. (1997). Turkey's labor force: A comparison across provinces and over time. METU Studies in Development, 24(4):531-547.

Torche, F., Valenzuela, E. (2011). Trust and reciprocity: A theoretical distinction of the sources of social capital. European Journal of Social Theory, 14(2):181-198.

Tu, Q., Bulte, E. (2010). Trust, market participation and economic outcomes: Evidence from rural China. World Development, 38(8), 1179-1190.

Uslaner, E. M. (2002). The moral foundations of trust. Cambridge: Cambridge University Press.

van Bastelaer, T., Leathers, H. (2006). Trust in lending: Social capital and joint liability seed loans in southern Zambia. World Development, 34(10), 1788-1807.

Yang, Y., Shen, K. (2010). Effects of social capital on technology innovation: An empirical analysis based on China's provincial panel data. Contemporary Finance \& Economics, 2010-08.

Zak, P. J., Knack, S. (2001). Trust and growth. The Economic Journal, 111(470):295-321. 
Figure 1a. Generalized trust across regions in Turkey, 2007.

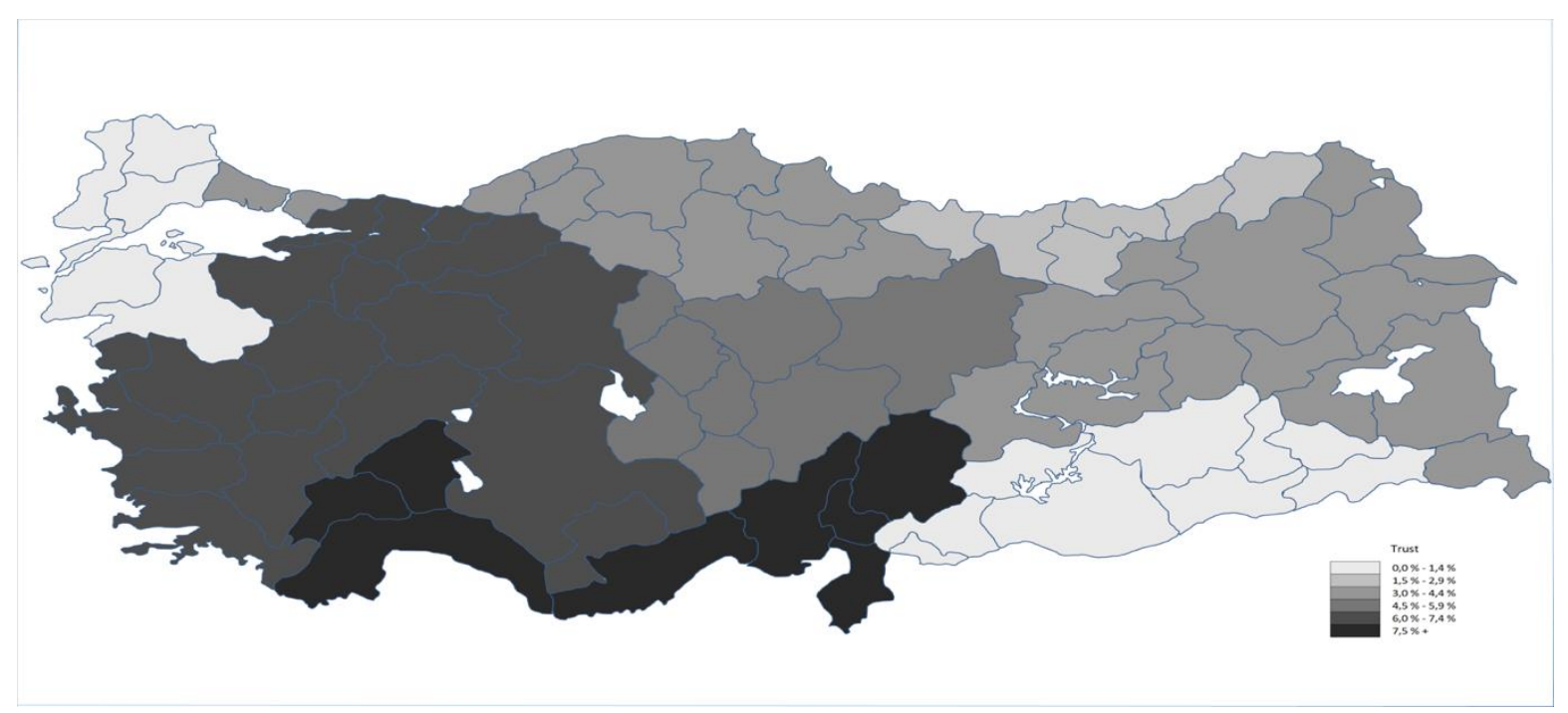

Note: The darker the shade is, the stronger generalized trust is.

Source of data: World Values Survey

Figure 1b. Average financial development between regions in Turkey, 2004-2010.

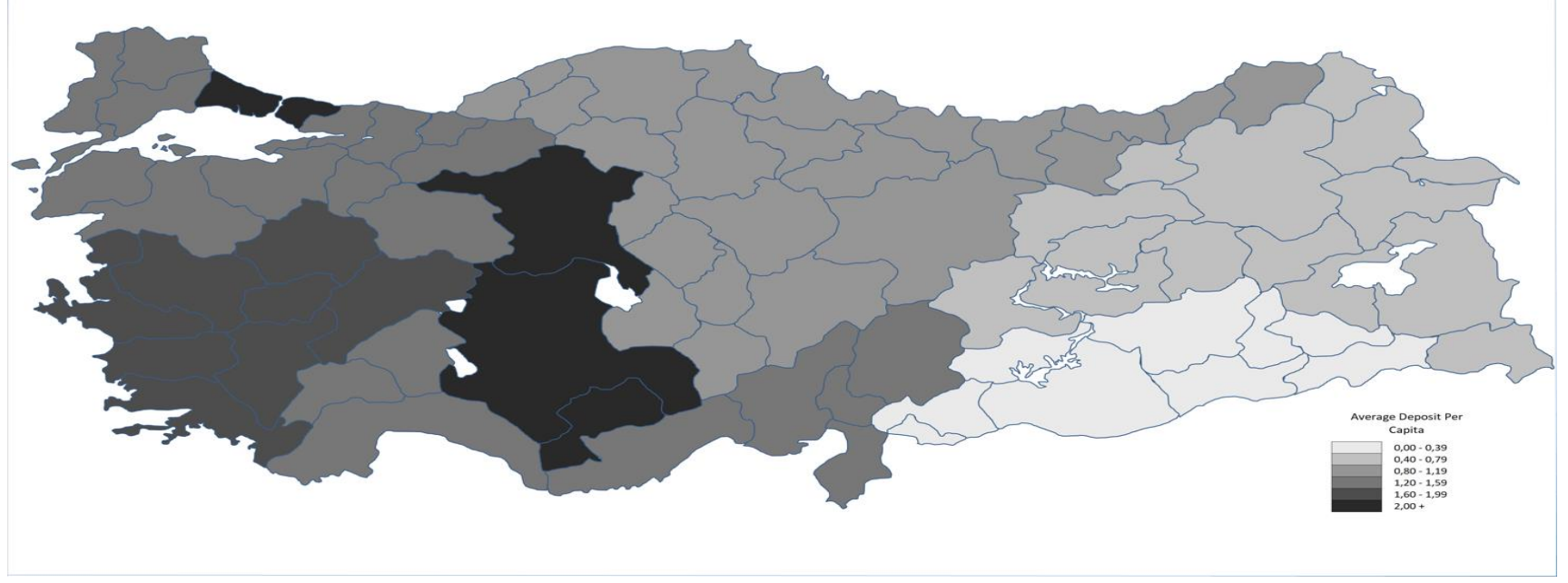

Note: The darker the shade is, the higher the level of financial development is.

Source of data: The Banks Association of Turkey 
Figure 2a. Generalized trust between regions in Turkey, 2012.

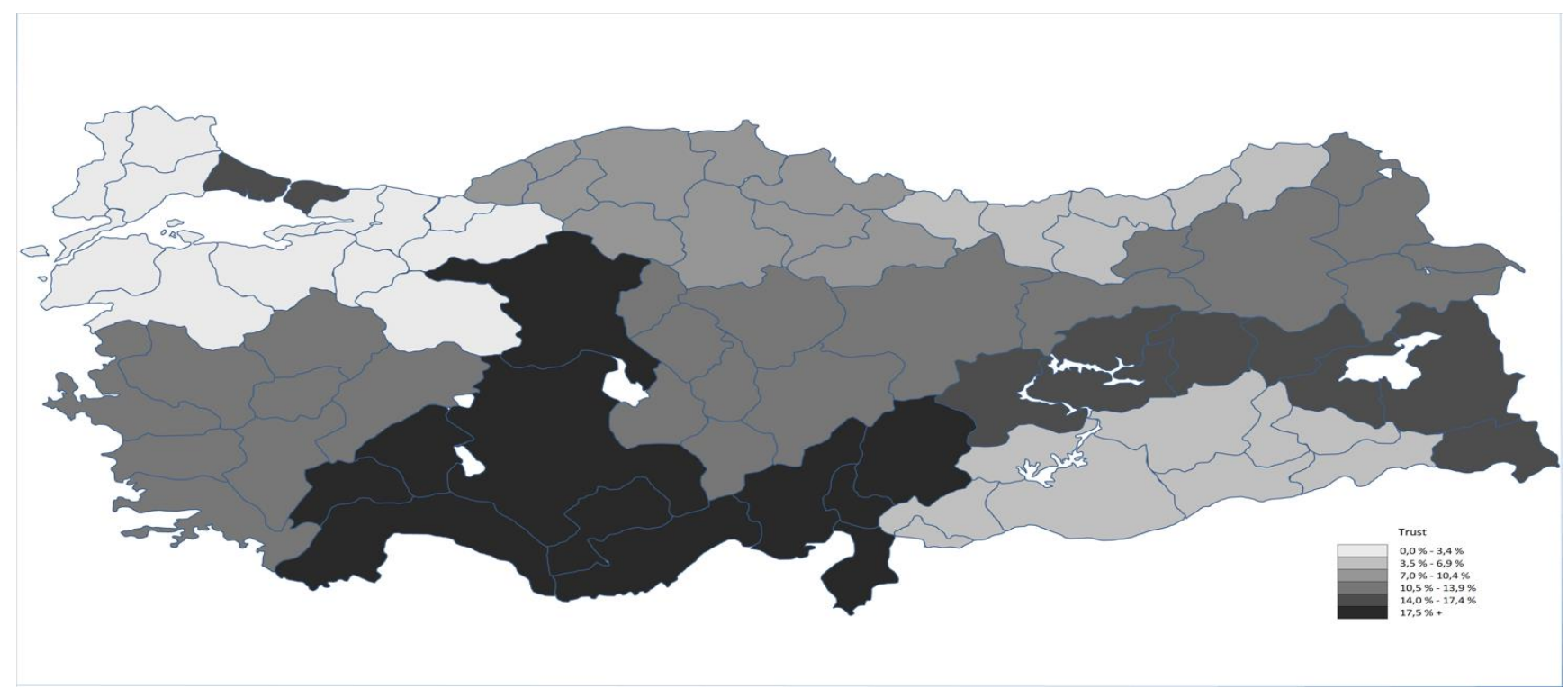

Note: The darker the shade is, the stronger generalized trust is.

Source of data: World Values Survey

Figure 2b. Average level of financial development between regions in Turkey, 2011-2017.

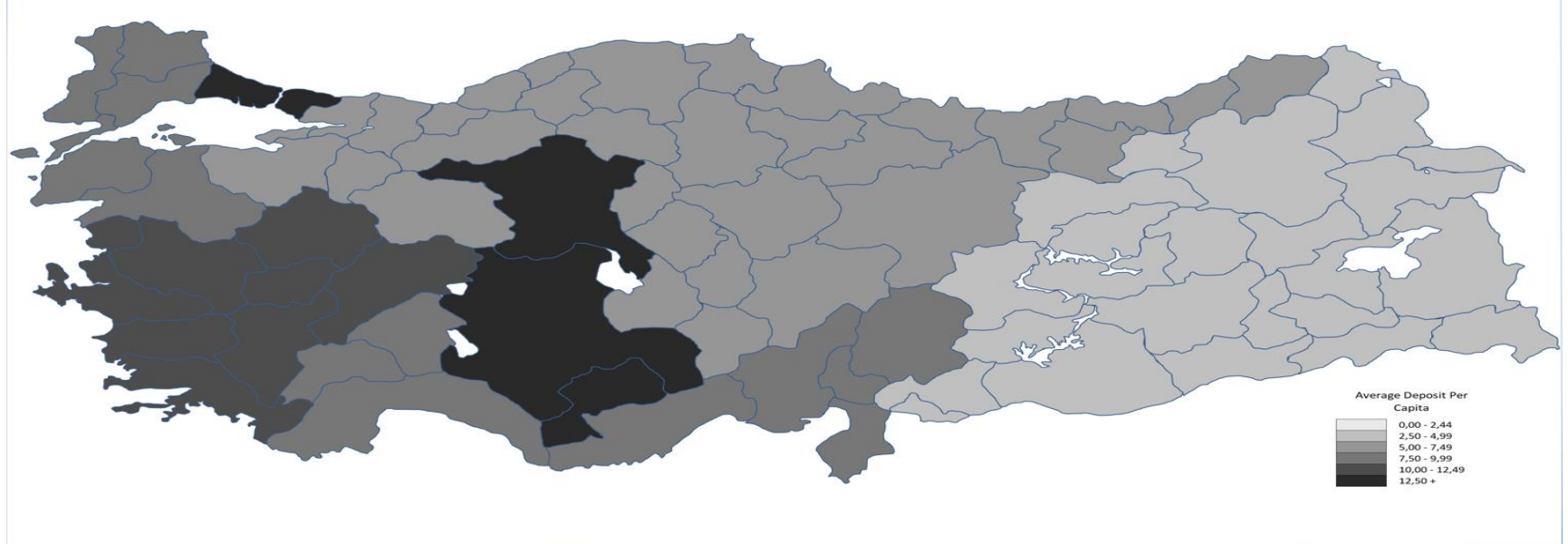

Note: The darker the shade is, the higher the level of financial development is Source of data: The Banks Association of Turkey 
Table 1. Summary statistics

\begin{tabular}{|c|c|c|c|c|c|}
\hline Variable & Obs. & Mean & Std. Dev. & Min & Max \\
\hline creditpercapita ('000) & 168 & 6.56 & 9.40 & 0.09 & 66.07 \\
\hline depositpercapita ('000) & 168 & 5.92 & 8.82 & 0.19 & 63.77 \\
\hline credit-to-income & 168 & 0.323 & .169 & 0.06 & 0.87 \\
\hline deposit-to-income & 168 & 0.320 & .177 & 0.11 & 0.86 \\
\hline credit_over_deposit & 168 & 1.081 & 0.462 & 0.26 & 2.86 \\
\hline generalizedtrust & 168 & 0.071 & .055 & 0 & 0.19 \\
\hline narrowtrust & 168 & 0.780 & .091 & 0.59 & 0.96 \\
\hline widetrust & 168 & 0.164 & .086 & 0.04 & 0.37 \\
\hline initialGDPgrowth & 168 & 94.31 & 1.706 & 91.93 & 96.89 \\
\hline dummy Istanbul & 168 & 0.083 & 0.277 & 0 & 1 \\
\hline fractionalization & 168 & .074 & 0.069 & 0 & .2 \\
\hline sector-services & 168 & 0.685 & 0.466 & 0 & 1 \\
\hline
\end{tabular}

Table 2. Correlation matrix

\begin{tabular}{|c|c|c|c|c|c|c|c|c|c|c|}
\hline Variables & $\begin{array}{l}\text { credit } \\
\text { percapita }\end{array}$ & $\begin{array}{c}\text { deposit } \\
\text { percapita }\end{array}$ & $\begin{array}{l}\text { credit-to- } \\
\text { income }\end{array}$ & $\begin{array}{l}\text { deposit-to- } \\
\text { income }\end{array}$ & $\begin{array}{l}\text { generalize } \\
\text { dtrust }\end{array}$ & $\begin{array}{l}\text { narrow } \\
\text { trust }\end{array}$ & widetrust & $\begin{array}{l}\text { initial } \\
\text { GDPgrowth }\end{array}$ & $\begin{array}{l}\text { fractionali } \\
\text { zation }\end{array}$ & $\begin{array}{l}\text { sector- } \\
\text { services }\end{array}$ \\
\hline creditpercapita & 1.000 & & & & & & & & & \\
\hline depositpercapita & 0.956 & 1.000 & & & & & & & & \\
\hline credit-to-income & 0.920 & 0.902 & 1.000 & & & & & & & \\
\hline deposit-to-income & 0.586 & 0.763 & 0.718 & 1.000 & & & & & & \\
\hline generalizedtrust & 0.547 & 0.538 & 0.641 & 0.438 & 1.000 & & & & & \\
\hline narrowtrust & 0.201 & 0.216 & 0.099 & 0.078 & 0.268 & 1.000 & & & & \\
\hline widetrust & 0.341 & 0.306 & 0.332 & 0.118 & 0.367 & 0.201 & 1.000 & & & \\
\hline initialGDPgrowth & 0.134 & 0.233 & 0.169 & 0.353 & 0.143 & 0.101 & -0.213 & 1.000 & & \\
\hline fractionalization & -0.249 & -0.377 & -0.161 & -0.312 & 0.086 & 0.040 & -0.032 & -0.115 & 1.000 & \\
\hline sector-services & -0.064 & -0.064 & 0.113 & 0.191 & 0.183 & -0.306 & -0.357 & 0.016 & 0.321 & 1.000 \\
\hline
\end{tabular}


Table 3a. The relationship between generalized trust and financial development in Turkey using regional data, 2004-2017.

\begin{tabular}{|c|c|c|c|c|}
\hline & \multicolumn{4}{|c|}{ IV regression } \\
\hline & creditpercapita & depositpercapita & credit-to-income & deposit-to-income \\
\hline \multirow[t]{2}{*}{ generalizedtrust } & $15.61^{* * * *}$ & $21.51^{* * *}$ & $2.860^{* * *}$ & $5.510^{* * * *}$ \\
\hline & $(7.69)$ & $(6.90)$ & $(11.51)$ & $(7.39)$ \\
\hline \multirow[t]{2}{*}{ sector-services } & $-0.436^{* * * *}$ & $-0.529^{* * * *}$ & -0.0231 & -0.0577 \\
\hline & $(-3.91)$ & $(-3.49)$ & $(-1.17)$ & $(-1.45)$ \\
\hline \multirow[t]{2}{*}{ dummy_Istanbul } & $1.419^{* * *}$ & $1.519^{* * *}$ & $0.238^{* * *}$ & $0.313^{* * *}$ \\
\hline & $(9.05)$ & $(7.89)$ & $(13.43)$ & $(7.77)$ \\
\hline \multirow[t]{2}{*}{ fractionalization } & $-5.328^{* * *}$ & $-7.108^{* * *}$ & $-0.572^{* * *}$ & $-1.083^{* * *}$ \\
\hline & $(-8.38)$ & $(-9.35)$ & $(-4.05)$ & $(-5.06)$ \\
\hline \multirow[t]{2}{*}{ initialGDPgrowth } & $-0.0906^{* * * *}$ & $-0.0774^{* *}$ & $-0.0168^{* * *}$ & $-0.0169^{*}$ \\
\hline & $(-3.47)$ & $(-2.15)$ & $(-3.51)$ & $(-1.69)$ \\
\hline Year dummies & yes & yes & yes & yes \\
\hline \multirow[t]{2}{*}{ Constant } & $7.249^{* * *}$ & $6.666^{* *}$ & $1.616^{* * *}$ & $1.696^{*}$ \\
\hline & $(2.95)$ & $(1.97)$ & $(3.57)$ & $(1.80)$ \\
\hline Obs & 168 & 168 & 168 & 168 \\
\hline F-stat & $66.44^{* * *}$ & $29.54^{* * *}$ & $54.33^{* * *}$ & $12.84^{* * *}$ \\
\hline Kleibergen-Paap LM stat & $29.23^{* * *}$ & $29.23^{* * *}$ & $29.23^{* * *}$ & $29.23^{* * *}$ \\
\hline Hansen $\mathrm{J}$ statistic & 2.678 & 3.620 & 1.762 & 1.572 \\
\hline p-value & 0.102 & 0.0571 & 0.184 & 0.210 \\
\hline Endogeneity test & $17.91^{* * *}$ & 1.909 & $29.05^{* * *}$ & $11.35^{* * *}$ \\
\hline
\end{tabular}

This table displays OLS and IV regression estimates of equation 1. The financial development indicators are: creditpercapita, which is the natural logarithm of regional credit per

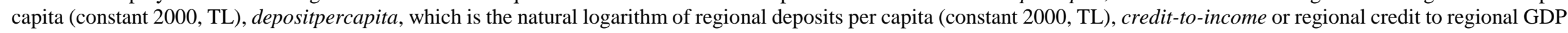
and deposit-to-income or regional deposits to regional GDP (constant 2000, TL). The key variable of interest is generalizedtrust, which is the proportion of people in each region who responded that most people can be trusted. This measure ranges from 0 to 1 . We also consider regional ethnic fractionalization (fractionalization) in our regressions. Control

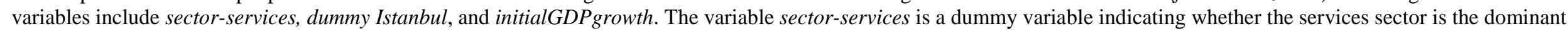
sector (or has the highest share in regional GDP). Meanwhile, dummy Istanbul is a dummy variable indicating whether the financial capital, Istanbul, is in the region and initialGDPgrowth is the average regional GDP growth between 2000 and 2003. T-statistics are in parentheses. Standard errors are corrected for heteroskedasticity. Note: ***

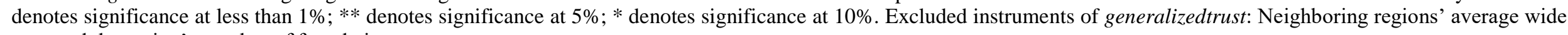
trust and the region's number of foundations. 
Table 3b. The relationship between generalized trust, different forms of trust, and financial development in Turkey using regional data, $2004-2017$.

\begin{tabular}{|c|c|c|c|c|}
\hline & \multicolumn{4}{|c|}{ IV regression } \\
\hline & creditpercapita & depositpercapita & credit-to-income & deposit-to-income \\
\hline \multirow[t]{2}{*}{ generalizedtrust } & -3.156 & 0.293 & -0.735 & -0.0805 \\
\hline & $(-0.57)$ & $(0.04)$ & $(-0.62)$ & $(-0.04)$ \\
\hline \multirow[t]{2}{*}{ narrowtrust } & 1.334 & 1.407 & 0.0816 & 0.170 \\
\hline & (1.57) & $(1.46)$ & $(0.44)$ & $(0.63)$ \\
\hline \multirow[t]{2}{*}{ widetrust } & $13.89^{* * *}$ & $15.89^{* * *}$ & $2.740^{* * *}$ & $4.287^{* * * *}$ \\
\hline & $(2.94)$ & $(2.87)$ & $(2.74)$ & $(2.80)$ \\
\hline \multirow[t]{2}{*}{ sector-services } & $1.122^{* *}$ & $1.241^{*}$ & $0.271^{* *}$ & $0.404^{* *}$ \\
\hline & $(2.16)$ & $(1.92)$ & $(2.44)$ & $(2.25)$ \\
\hline \multirow{2}{*}{ dummy_Istanbul } & $0.880^{* * *}$ & $0.892^{* * *}$ & $0.119^{* *}$ & 0.128 \\
\hline & $(3.74)$ & $(3.03)$ & $(2.19)$ & (1.58) \\
\hline \multirow[t]{2}{*}{ fractionalization } & $-6.230^{* * * *}$ & $-8.123^{* * *}$ & $-0.714^{* * *}$ & $-1.316^{* * *}$ \\
\hline & $(-6.59)$ & $(-7.49)$ & $(-3.96)$ & $(-4.52)$ \\
\hline \multirow[t]{2}{*}{ initialGDPgrowth } & $0.168^{*}$ & $0.219^{*}$ & $0.0359^{*}$ & $0.0649^{* *}$ \\
\hline & $(1.76)$ & $(1.94)$ & $(1.78)$ & $(2.11)$ \\
\hline Year dummies & yes & yes & yes & yes \\
\hline \multirow[t]{2}{*}{ Constant } & $-20.17^{* *}$ & $-24.65^{* *}$ & $-3.811^{*}$ & $-6.770^{* *}$ \\
\hline & $(-2.06)$ & $(-2.14)$ & $(-1.84)$ & $(-2.14)$ \\
\hline Obs & 168 & 168 & 168 & 168 \\
\hline F-stat & $39.23^{* * *}$ & $30.02^{* * *}$ & $11.58^{* * *}$ & $12.10^{* * *}$ \\
\hline Kleibergen Paap LM stat & $7.589^{* *}$ & $7.589^{* *}$ & $7.589^{* *}$ & $7.589^{* *}$ \\
\hline Hansen J stat & 1.236 & 0.319 & 1.471 & 0.300 \\
\hline p-value & 0.266 & 0.572 & 0.225 & 0.584 \\
\hline Endogeneity test & $33.97^{* * *}$ & $30.07^{* * *}$ & $36.07^{* * *}$ & $31.85^{* * *}$ \\
\hline
\end{tabular}

This table displays OLS and IV regression estimates of equation 2. The financial development indicators are: creditpercapita, which is the natural logarithm of regional credit per capita (constant 2000, TL), depositpercapita, which is the natural logarithm of regional deposits per capita (constant 2000, TL), credit-to-income or regional credit to regional GDP

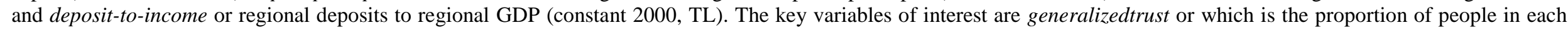
region who responded that most people can be trusted, narrowtrust or the proportion of people in each region who responded that they trust people they know personally somewhat or completely, and widetrust or the proportion of people in each region who responded that they trust people they meet for the first time somewhat or completely. These measures

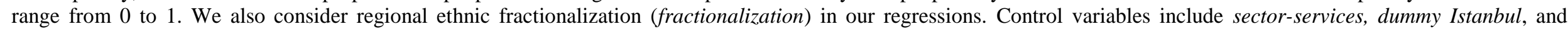
initialGDPgrowth. The variable sector-services is a dummy variable indicating whether the services sector is the dominant sector (or has the highest share in regional GDP). Meanwhile, dummy Istanbul is a dummy variable indicating whether the financial capital, Istanbul, is in the region and initialGDPgrowth is the average regional GDP growth

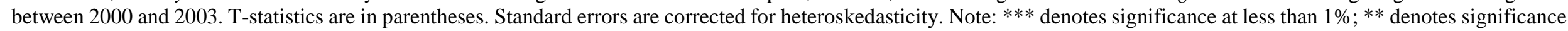
at $5 \%$; * denotes significance at $10 \%$. Excluded instruments of generalizedtrust and widetrust: neighboring regions' average level of narrow trust, generalized trust, and the number of foundations (average for 2004-2011 and 2012 to 2017). 
Table 4a. Impact of the interactions between narrow trust and generalized trust, and between narrow trust and wide trust on financial development in Turkey using regional data, 2004-2017.

\begin{tabular}{|c|c|c|c|c|c|c|c|c|}
\hline & \multicolumn{8}{|c|}{ Instrumental Variable Regression } \\
\hline & creditpercapita & depositpercapita & credit-to-income & deposit-to-income & creditpercapita & depositpercapita & credit-to-income & deposit-to-income \\
\hline & \multicolumn{4}{|c|}{ Eq. $3 \mathrm{a}$} & \multicolumn{4}{|c|}{ Eq. $3 \mathrm{~b}$} \\
\hline generalizedtrust & $\begin{array}{l}-45.24 \\
(-1.24)\end{array}$ & $\begin{array}{l}-73.83 \\
(-1.39)\end{array}$ & $\begin{array}{c}-9.484^{* * *} \\
(-2.00)\end{array}$ & $\begin{array}{l}-21.37^{*} \\
(-1.79)\end{array}$ & $\begin{array}{c}20.52^{* * * *} \\
(3.98)\end{array}$ & $\begin{array}{c}28.02^{* * *} \\
(3.70)\end{array}$ & $\begin{array}{c}2.695^{* * *} \\
(2.98)\end{array}$ & $\begin{array}{c}5.683^{* * *} \\
(2.98)\end{array}$ \\
\hline narrowtrust & $\begin{array}{c}-8.085^{* *} \\
(-2.55)\end{array}$ & $\begin{array}{c}-12.12^{* *} \\
(-2.56)\end{array}$ & $\begin{array}{c}-1.471^{* * * *} \\
(-3.43)\end{array}$ & $\begin{array}{c}-3.091^{* * * *} \\
(-2.81)\end{array}$ & $\begin{array}{l}-13.60^{*} \\
(-1.88)\end{array}$ & $\begin{array}{c}-20.38^{* *} \\
(-1.98)\end{array}$ & $\begin{array}{c}-3.375^{* *} \\
(-2.34)\end{array}$ & $\begin{array}{c}-5.793^{* *} \\
(-2.18)\end{array}$ \\
\hline generalizedtrust*narrowtrust & $\begin{array}{l}89.20^{*} \\
(1.82)\end{array}$ & $\begin{array}{l}138.1^{*} \\
(1.92)\end{array}$ & $\begin{array}{c}16.47^{* * * *} \\
(2.61)\end{array}$ & $\begin{array}{c}36.67^{* * *} \\
(2.27)\end{array}$ & & & & \\
\hline widetrust & $\begin{array}{l}-5.444 \\
(-1.38)\end{array}$ & $\begin{array}{l}-8.816 \\
(-1.57)\end{array}$ & $\begin{array}{l}-0.646 \\
(-1.30)\end{array}$ & $\begin{array}{l}-2.016^{*} \\
(-1.68)\end{array}$ & $\begin{array}{l}-63.56^{*} \\
(-1.73)\end{array}$ & $\begin{array}{c}-97.40^{*} \\
(-1.86)\end{array}$ & $\begin{array}{c}-15.97^{* * *} \\
(-2.28)\end{array}$ & $\begin{array}{c}-28.16^{* *} \\
(-2.15)\end{array}$ \\
\hline widetrust $*_{\text {narrowtrust }}$ & & & & & $\begin{array}{l}77.31^{*} \\
(1.70)\end{array}$ & $\begin{array}{l}118.0^{*} \\
(1.83)\end{array}$ & $\begin{array}{c}19.97^{* *} \\
(2.33)\end{array}$ & $\begin{array}{c}34.58^{* * *} \\
(2.16)\end{array}$ \\
\hline sector-services & $\begin{array}{c}-1.718^{* * *} \\
(-3.05)\end{array}$ & $\begin{array}{c}-2.436^{* * * *} \\
(-2.95)\end{array}$ & $\begin{array}{c}-0.185^{* * * *} \\
(-2.63)\end{array}$ & $\begin{array}{c}-0.454^{* *} \\
(-2.53)\end{array}$ & $\begin{array}{c}-0.767^{* *} \\
(-2.30)\end{array}$ & $\begin{array}{c}-0.968^{* *} \\
(-2.04)\end{array}$ & $\begin{array}{c}0.00652 \\
(0.10)\end{array}$ & $\begin{array}{c}-0.0560 \\
(-0.47)\end{array}$ \\
\hline dummy_Istanbul & $\begin{array}{c}1.745^{* * * *} \\
(4.34)\end{array}$ & $\begin{array}{c}2.071^{* * * *} \\
(3.59)\end{array}$ & $\begin{array}{c}0.284^{* * * *} \\
(5.82)\end{array}$ & $\begin{array}{c}0.453^{* * * *} \\
(3.77)\end{array}$ & $\begin{array}{c}1.052^{* * * *} \\
(3.43)\end{array}$ & $\begin{array}{l}1.004^{* *} \\
(2.40)\end{array}$ & $\begin{array}{c}0.131^{* * * *} \\
(2.76)\end{array}$ & $\begin{array}{l}0.156^{*} \\
(1.68)\end{array}$ \\
\hline initialGDPgrowth & $\begin{array}{l}-0.133 \\
(-1.52)\end{array}$ & $\begin{array}{l}-0.154 \\
(-1.21)\end{array}$ & $\begin{array}{c}-0.0170 \\
(-1.44)\end{array}$ & $\begin{array}{c}-0.0309 \\
(-1.10)\end{array}$ & $\begin{array}{l}0.0191 \\
(0.22)\end{array}$ & $\begin{array}{c}0.0798 \\
(0.68)\end{array}$ & $\begin{array}{c}0.0190 \\
(1.25)\end{array}$ & $\begin{array}{c}0.0357 \\
(1.31)\end{array}$ \\
\hline Year dummies & yes & yes & yes & yes & yes & yes & yes & yes \\
\hline Constant & $\begin{array}{l}18.24^{*} \\
(1.81)\end{array}$ & $\begin{array}{l}24.48^{*} \\
(1.65)\end{array}$ & $\begin{array}{l}2.880^{* * *} \\
(2.16) \\
\end{array}$ & $\begin{array}{l}5.742^{*} \\
(1.74) \\
\end{array}$ & $\begin{array}{l}7.382 \\
(1.15) \\
\end{array}$ & $\begin{array}{l}7.680 \\
(0.86) \\
\end{array}$ & $\begin{array}{l}0.823 \\
(0.66) \\
\end{array}$ & $\begin{array}{l}1.252 \\
(0.56) \\
\end{array}$ \\
\hline Obs & 168 & 168 & 168 & 168 & 168 & 168 & 168 & 168 \\
\hline F-stat & $28.50^{* * *}$ & $12.99^{* * *}$ & $35.26^{* * *}$ & $12.24^{* * *}$ & $21.51^{* * *}$ & $8.403^{* * *}$ & $21.88^{* * *}$ & $7.192^{* * *}$ \\
\hline Kleibergen Paap LM stat & $11.45^{* * *}$ & $11.45^{* * *}$ & $11.45^{* * *}$ & $11.45^{* * *}$ & $6.938^{* *}$ & $6.938^{* *}$ & $6.938^{* *}$ & $6.938^{* *}$ \\
\hline Hansen $\mathbf{J}$ test & 0.117 & 0.107 & 3.695 & 0.658 & 0.878 & 1.199 & 0.0156 & 0.596 \\
\hline p-value & 0.732 & 0.744 & 0.0546 & 0.417 & 0.349 & 0.273 & 0.901 & 0.440 \\
\hline Endogeneity test & $37.16^{* * *}$ & $33.06^{* * *}$ & $30.85^{* * *}$ & $28.88^{* * *}$ & $31.23^{* * *}$ & $25.32^{* * *}$ & $42.13^{* * *}$ & $24.64^{* * *}$ \\
\hline
\end{tabular}

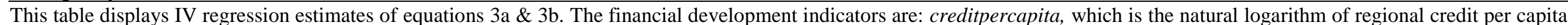

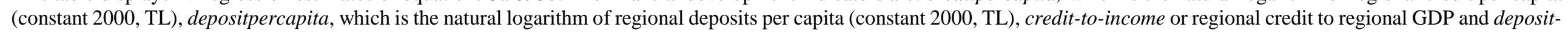

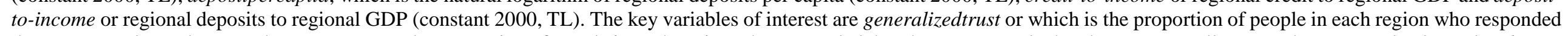

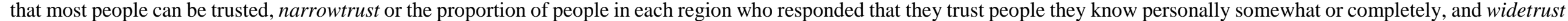

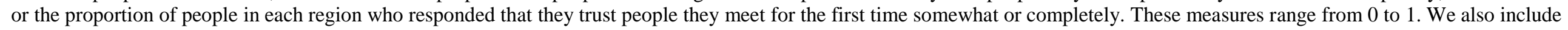

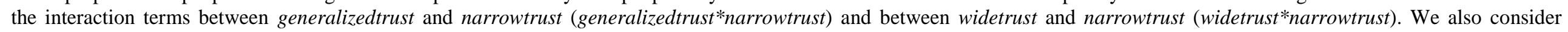

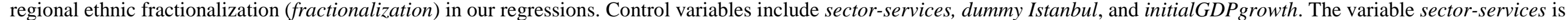

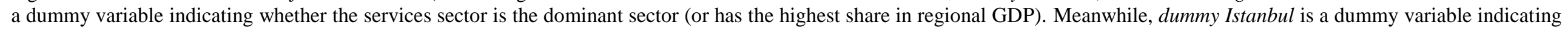

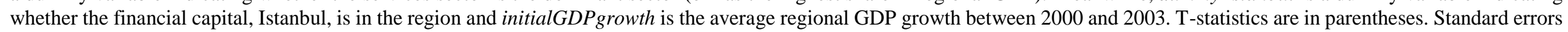

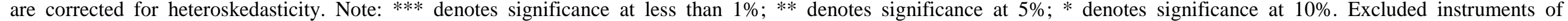

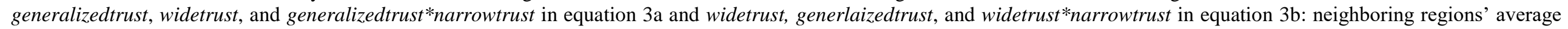

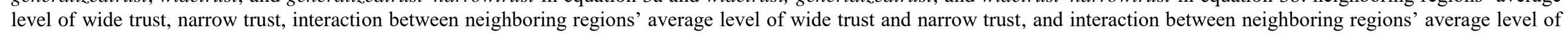
narrow trust and narrow trust. 
Table 4b. Marginal effects of generalized trust according to different levels of narrow trust in Turkey using regional data, $2004-2017$.

\begin{tabular}{|l|l|l|l|l|}
\hline & \multicolumn{1}{|c|}{ creditpercapita } & \multicolumn{1}{|c|}{ depositpercapita } & \multicolumn{1}{|c|}{ credit-to-income } & \multicolumn{1}{c|}{ deposit-to-income } \\
\hline Low narrow trust (P10) & $15.410^{* *}$ & $20.109^{* *}$ & $1.713^{* *}$ & $3.561^{*}$ \\
& $(6.682)$ & $(9.608)$ & $(0.857)$ & $(2.132)$ \\
\hline Median narrow trust (P50) & $23.437 * * *$ & $32.542^{* * *}$ & $3.195^{* * *}$ & $6.861^{* * *}$ \\
& $(6.368)$ & $(9.382)$ & $(0.781)$ & $(2.097)$ \\
\hline High narrow trust (P90) & $37.709^{* * *}$ & $54.645^{* * *}$ & $5.830^{* * *}$ & $12.728^{* * *}$ \\
& $(11.392)$ & $(16.961)$ & $(1.408)$ & $(3.819)$ \\
\hline
\end{tabular}

*delta standard errors in parentheses

Table 4c. Marginal effects of wide trust according to different levels of narrow trust in Turkey using regional data, $2004-2017$.

\begin{tabular}{|l|l|l|l|l|}
\hline & \multicolumn{1}{|c|}{ creditpercapita } & \multicolumn{1}{|c|}{ depositpercapita } & \multicolumn{1}{c|}{ deposit-to-income } \\
\hline Low narrow trust (P10) & $-10.99^{*}$ to-income & $-2.387^{*}$ & $-4.647^{*}$ \\
& $(6.397)$ & $-17.180^{*}$ & $(1.269)$ & $(2.424)$ \\
\hline Median narrow trust (P50) & -4.030 & $(9.392)$ & -0.589 & -1.535 \\
& $(3.296)$ & -6.562 & $(0.682)$ & $(1.289)$ \\
\hline High narrow trust (P90) & 8.339 & $(4.877)$ & $2.606^{* *}$ & $3.997^{*}$ \\
& $(6.337)$ & 12.313 & $(1.174)$ & $(2.098)$ \\
\hline
\end{tabular}

*delta standard errors in parentheses 
Table 5a. Link between generalized trust and financial development dependent on regional fractionalization in Turkey, $2004-2017$.

\begin{tabular}{|c|c|c|c|c|}
\hline & \multicolumn{4}{|c|}{ Instrumental variable (IV) regression } \\
\hline & creditpercapita & depositpercapita & credit-to-income & deposit-to-income \\
\hline \multirow{2}{*}{ generalizedtrust } & $20.01^{* * * *}$ & $29.62^{* * * *}$ & $2.677^{* * * *}$ & $6.298^{* * * *}$ \\
\hline & $(4.49)$ & $(4.41)$ & $(5.23)$ & $(4.24)$ \\
\hline \multirow[t]{2}{*}{ fractionalization } & $-2.334^{* *}$ & -2.038 & 0.113 & 0.158 \\
\hline & $(-2.56)$ & $(-1.64)$ & $(0.98)$ & $(0.62)$ \\
\hline \multirow{2}{*}{ generalizedtrust ${ }^{*}$ fractionalization } & $-48.45^{* * *}$ & $-82.62^{* * * *}$ & $-10.51^{* * *}$ & $-19.49^{* * *}$ \\
\hline & $(-2.85)$ & $(-3.65)$ & $(-4.60)$ & $(-4.05)$ \\
\hline \multirow[t]{2}{*}{ widetrust } & -2.580 & -4.238 & $-0.630^{* *}$ & $-1.050^{*}$ \\
\hline & $(-1.34)$ & $(-1.55)$ & $(-2.57)$ & $(-1.85)$ \\
\hline \multirow[t]{2}{*}{ narrowtrust } & -0.0429 & -0.0584 & 0.00738 & -0.0474 \\
\hline & $(-0.07)$ & $(-0.06)$ & $(0.10)$ & $(-0.26)$ \\
\hline Control variables & yes & yes & yes & yes \\
\hline Year dummies & yes & yes & yes & yes \\
\hline \multirow{2}{*}{ Constant } & $10.85^{* *}$ & $12.79^{*}$ & $2.096^{* * *}$ & $2.798^{*}$ \\
\hline & $(2.33)$ & $(1.93)$ & $(3.11)$ & $(1.89)$ \\
\hline Obs. & 168 & 168 & 168 & 168 \\
\hline F-stat & $60.60^{* * *}$ & $34.51^{* * *}$ & $88.63^{* * * *}$ & $14.90^{* * *}$ \\
\hline Kleibergen Paap LM stat & $19.70^{* * *}$ & $19.70^{* * * *}$ & $19.70^{* * * *}$ & $19.70^{* * *}$ \\
\hline Hansen J stat & 1.208 & 0.622 & 3.224 & 0.363 \\
\hline p-value & 0.272 & 0.430 & 0.0726 & 0.547 \\
\hline Endogeneity test & $34.01^{* * *}$ & $41.27^{* * *}$ & $18.23^{* * *}$ & $25.84^{* * *}$ \\
\hline
\end{tabular}

This table displays IV regression estimates of equation 4a. The financial development indicators are: creditpercapita, which is the natural logarithm of regional credit per capita (constant 2000, TL),

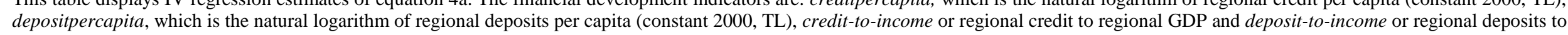

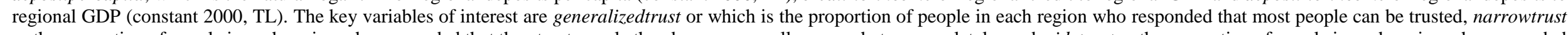

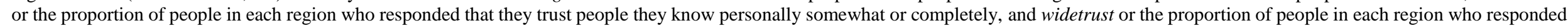

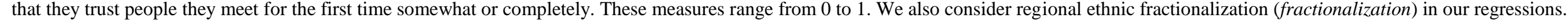

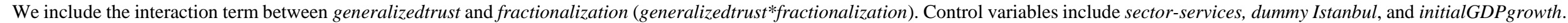

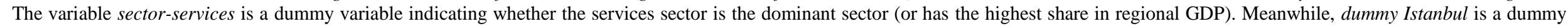

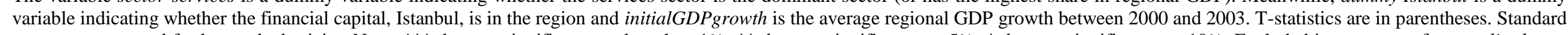

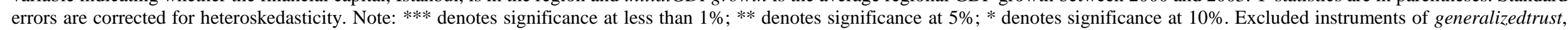

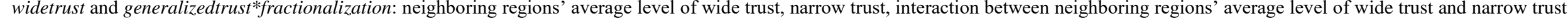
with fractionalization. 
Table 5b. Marginal effect of generalized trust according to different levels of ethnic fractionalization using regional data in Turkey, $2004-2017$.

\begin{tabular}{|c|c|c|c|c|}
\hline Ethnic fractionalization & creditpercapita & depositpercapita & credit-to-income & deposit-to-income \\
\hline Low (P10) & $\begin{array}{c}19.529 * * * \\
(4.327)\end{array}$ & $\begin{array}{c}28.798 * * * \\
(6.529)\end{array}$ & $\begin{array}{c}2.572 * * * \\
(0.495)\end{array}$ & $\begin{array}{c}6.103 * * * \\
(1.447)\end{array}$ \\
\hline Median (P50) & $\begin{array}{c}17.349 * * * \\
(3.799)\end{array}$ & $\begin{array}{c}25.080 * * * \\
(5.741)\end{array}$ & $\begin{array}{c}2.099 * * * \\
(0.432)\end{array}$ & $\begin{array}{c}5.226 * * * \\
(1.277)\end{array}$ \\
\hline High (P90) & $\begin{array}{c}10.324 * * * \\
(2.922)\end{array}$ & $\begin{array}{c}13.100 * * * \\
(3.995)\end{array}$ & $\begin{array}{c}0.576 \\
(0.374)\end{array}$ & $\begin{array}{c}2.399 * * * \\
(0.882)\end{array}$ \\
\hline
\end{tabular}

*delta standard errors in parentheses 
Table 6b. Marginal effect of narrow trust according to different levels of ethnic fractionalization using regional data in Turkey, $2004-2017$.

\begin{tabular}{|l|c|c|c|c|}
\hline Ethnic fractionalization & creditpercapita & depositpercapita & credit-to-income & deposit-to-income \\
\hline Low (P10) & 0.531 & 0.858 & -0.095 & -0.138 \\
& $(0.7183)$ & $(1.033)$ & $(0.111)$ & $(0.230)$ \\
\hline Median (P50) & -0.555 & -0.762 & $-0.260^{* * *}$ & $(0.283$ \\
& $(0.620)$ & $(0.887)$ & $-0.101)$ & $(0.188)$ \\
\hline High (P90) & $-5.055^{* *}$ & $-7.475^{* *}$ & -0.887 & $(0.395)$ \\
\hline
\end{tabular}

*delta standard errors in parentheses

Table 6c. Marginal effect of wide trust according to different levels of ethnic fractionalization using regional data in Turkey, $2004-2017$.

\begin{tabular}{|l|c|c|c|c|}
\hline Ethnic fractionalization & creditpercapita & depositpercapita & credit-to-income & deposit-to-income \\
\hline Low (P10) & $6.601 * * *$ & $10.797 * * *$ & $2.492^{* *}$ & $(1.164)$ \\
& $(2.550)$ & $(3.484)$ & $2.953^{* * *}$ & $(0.883)$ \\
\hline Median (P50) & $9.135 * * *$ & $12.763 * * *$ & $(1.152)$ & $3.168^{* * *}$ \\
& $(2.431)$ & $(3.408)$ & $4.862^{* * *}$ & $(0.862)$ \\
\hline High (P90) & $19.631^{* * *}$ & $20.907 * * *$ & $(1.454)$ & $(1.277)$ \\
& $(3.395)$ & $(4.818)$ & \\
\hline
\end{tabular}

*delta standard errors in parentheses 


\section{Appendix}

Appendix A

Trust in banks and financial development in Turkey, 2011-2017.

\begin{tabular}{lcccc}
\hline & \multicolumn{3}{c}{ Instrumental variable (IV) regression } \\
& creditpercapita & depositpercapita & credit-to-income & deposit-to-income \\
\hline generalizedtrust & 1.710 & $4.465^{*}$ & 0.0948 & 0.842 \\
& $(1.02)$ & $(1.92)$ & $(0.17)$ & $(1.16)$ \\
banktrust & $4.555^{* * *}$ & $4.526^{* * *}$ & $1.353^{* * *}$ & $1.375^{* * *}$ \\
& $(5.29)$ & $(4.10)$ & $(4.52)$ & $(3.80)$ \\
narrowtrust & $2.181^{* * *}$ & $2.676^{* * *}$ & $0.425^{* *}$ & $0.654^{* * *}$ \\
& $(4.10)$ & $(4.53)$ & $(2.37)$ & $(3.41)$ \\
fractionalization & $-4.078^{* * * *}$ & $-6.750^{* * *}$ & $-0.360^{* *}$ & $-0.992^{* * *}$ \\
& $(-8.78)$ & $(-10.60)$ & $(-2.36)$ & $(-4.98)$ \\
sector-services & -0.0325 & -0.0534 & 0.0655 & 0.0690 \\
& $(-0.23)$ & $(-0.32)$ & $(1.56)$ & $(1.38)$ \\
dummy_Istanbul & $1.746^{* * *}$ & $1.929^{* * *}$ & $0.422^{* * * *}$ & $0.495^{* * *}$ \\
& $(16.66)$ & $(15.15)$ & $(9.75)$ & $(11.99)$ \\
initialGDPgrowth & 0.0349 & 0.0540 & 0.0131 & 0.0220 \\
& $(0.96)$ & $(1.17)$ & $(1.17)$ & $(1.57)$ \\
Year dummies & yes & yes & yes & yes \\
Constant & -5.254 & -7.491 & -1.773 & $-2.816^{*}$ \\
& $(-1.35)$ & $(-1.49)$ & $(-1.47)$ & $(-1.83)$ \\
\hline N & 84 & 84 & 84 & 84 \\
F-stat & $351.9^{* * *}$ & $252.7^{* * *}$ & $28.54^{* * *}$ & $186.6^{* * *}$ \\
Kleibergen Paap LM stat & $9.942^{* * *}$ & $9.942^{* * *}$ & $9.942^{* * *}$ & $9.942^{* * *}$ \\
Hansen J stat & 0.708 & 1.347 & 0.0558 & 2.602 \\
p-value & 0.400 & 0.246 & 0.813 & 0.107 \\
Endogeneity test & $35.47^{* * *}$ & $31.28^{* * *}$ & $23.81^{* * *}$ & $23.31^{* * *}$ \\
\hline
\end{tabular}

This table displays IV regression estimates of equation 2. The financial development indicators are: creditpercapita, which is the natural logarithm of regional credit per capita (constant 2000, TL), depositpercapita, which is the natural logarithm of regional deposits per capita (constant 2000, TL), credit-to-income or regional credit to regional GDP and deposit-to-income or regional deposits to regional GDP (constant 2000, TL). The key variables of interest are generalizedtrust or which is the proportion of people in each region who responded that most people can be trusted, narrowtrust or the proportion of people in each region who responded that they trust people they know personally somewhat or completely, and banktrust proportion of people in each region who responded that they have a great deal or quite a lot of confidence in banks. These measures range from 0 to 1 . We also consider regional ethnic fractionalization (fractionalization) in our regressions. Control variables include sector-services, dummy Istanbul, and initialGDPgrowth. The variable sector-services is a dummy variable indicating whether the services sector is the dominant sector (or has the highest share in regional GDP). Meanwhile, dummy Istanbul is a dummy variable indicating whether the financial capital, Istanbul, is in the region and initialGDPgrowth is the average regional GDP growth between 2000 and 2003. T-statistics are in parentheses. Standard errors are corrected for heteroskedasticity. Note: *** denotes significance at less than $1 \% ; * *$ denotes significance at $5 \%$; denotes significance at $10 \%$. Variables treated as endogenous: generalizedtrust, banktrust; Excluded instruments: average generalizedtrust, banktrust, and narrowtrust of neighboring regions. 


\section{Appendix B}

Table B1. Trust and credit intermediation from stable funds, 2004-2017.

\begin{tabular}{|c|c|c|c|c|c|c|c|}
\hline \multirow[b]{2}{*}{ generalizedtrust } & \multicolumn{2}{|l|}{ OLS } & \multicolumn{4}{|c|}{$\begin{array}{l}\text { Instrumental variable (IV) regression } \\
\text { credit_over_deposit }\end{array}$} & \multirow[b]{2}{*}{$\begin{array}{c}-5.084^{* * *} \\
(-4.06)\end{array}$} \\
\hline & $\begin{array}{c}-1.928^{* * *} \\
(-4.10)\end{array}$ & $\begin{array}{c}-3.443^{* * *} \\
(-2.58)\end{array}$ & $\begin{array}{c}42.46^{* *} \\
(2.25)\end{array}$ & $\begin{array}{l}-2.209 \\
(-1.45)\end{array}$ & $\begin{array}{c}-15.58^{* * * *} \\
(-3.43)\end{array}$ & $\begin{array}{c}-12.20^{* * * *} \\
(-4.10)\end{array}$ & \\
\hline narrowtrust & $\begin{array}{l}-0.448^{*} \\
(-1.93)\end{array}$ & $\begin{array}{l}-0.172 \\
(-0.62)\end{array}$ & $\begin{array}{c}5.009^{* * *} \\
(2.81)\end{array}$ & $\begin{array}{l}2.699^{* *} \\
(2.31)\end{array}$ & $\begin{array}{l}0.691 \\
(0.95)\end{array}$ & $\begin{array}{c}-3.233^{* *} \\
(-2.31)\end{array}$ & $\begin{array}{c}1.391^{* * *} \\
(3.98)\end{array}$ \\
\hline widetrust & $\begin{array}{r}0.0927 \\
(0.40)\end{array}$ & $\begin{array}{l}-0.528 \\
(-0.76)\end{array}$ & $\begin{array}{l}2.872 \\
(1.63)\end{array}$ & $\begin{array}{l}7.940 \\
(1.22)\end{array}$ & $\begin{array}{l}-0.870 \\
(-0.52)\end{array}$ & $\begin{array}{l}8.581^{* *} \\
(2.48)\end{array}$ & $\begin{array}{c}-5.966^{* * *} \\
(-3.96)\end{array}$ \\
\hline Control variables & yes & yes & yes & yes & yes & yes & yes \\
\hline $\begin{array}{l}\text { Year dummies } \\
\text { fractionalization }\end{array}$ & $\begin{array}{c}\text { yes } \\
2.445^{\text {*** }} \\
(6.04)\end{array}$ & $\begin{array}{c}\text { yes } \\
2.482^{* * * *} \\
(6.45)\end{array}$ & yes & yes & $\begin{array}{c}\text { yes } \\
-1.031 \\
(-0.88)\end{array}$ & $\begin{array}{c}\text { yes } \\
-50.69^{* * *} \\
(-2.70)\end{array}$ & $\begin{array}{c}\text { yes } \\
-6.365^{\text {*** }} \\
(-4.36)\end{array}$ \\
\hline generalizedtrust $*$ narrowtrust & & & $\begin{array}{l}-64.48^{* *} \\
(-2.53)\end{array}$ & & & & \\
\hline widetrust ${ }^{*}$ narrowtrust & & & & $\begin{array}{c}-15.40^{* *} \\
(-2.03)\end{array}$ & & & \\
\hline generalizedtrust $*$ fractionalization & & & & & $\begin{array}{c}62.11^{* * *} \\
(2.93)\end{array}$ & & \\
\hline narrowtrust $*$ fractionalization & & & & & & $\begin{array}{c}69.99^{* * *} \\
(2.82)\end{array}$ & \\
\hline widetrust $*$ fractionalization & & & & & & & $\begin{array}{c}60.56^{* * *} \\
(6.08)\end{array}$ \\
\hline Constant & $\begin{array}{c}4.119^{* * *} \\
(3.86) \\
\end{array}$ & $\begin{array}{l}4.596^{* *} \\
(2.21) \\
\end{array}$ & $\begin{array}{l}-2.583 \\
(-0.51) \\
\end{array}$ & $\begin{array}{c}12.49^{* * *} \\
(4.73)\end{array}$ & $\begin{array}{r}3.404 \\
(1.01) \\
\end{array}$ & $\begin{array}{l}-1.764 \\
(-0.44)\end{array}$ & $\begin{array}{l}-3.693 \\
(-1.16) \\
\end{array}$ \\
\hline Obs & 168 & 168 & 168 & 168 & 168 & 168 & 168 \\
\hline F-stat & $24.62^{* * *}$ & $24.15^{* * *}$ & $6.901^{* * *}$ & $9.560^{* * *}$ & $7.056^{* * *}$ & $6.602^{* * *}$ & $31.94^{* * *}$ \\
\hline Kleibergen Paap LM test & & $16.82^{* * *}$ & $11.45^{* * *}$ & $12.52^{* * *}$ & $9.714^{* * *}$ & $6.737^{* * *}$ & $18.62^{* * *}$ \\
\hline Hansen $\mathbf{J}$ test & & 2.714 & 0.0310 & 0.0808 & 2.679 & 0.163 & 1.711 \\
\hline p-value & & 0.0995 & 0.860 & 0.776 & 0.102 & 0.687 & 0.425 \\
\hline Endogeneity test & & $7.684^{* *}$ & $32.55^{* * *}$ & $31.42^{* * *}$ & $38.65^{* * *}$ & $34.50^{* * *}$ & $40.97^{* * *}$ \\
\hline
\end{tabular}

This table displays OLS and IV regression estimates of equations 2, 3a, 3b, 4a, 4b, and 4c. The dependent variable is credit to deposit ratio (credit_over_deposit) (constant 2000, TL). The key variables of interest are generalizedtrust or which is the proportion of people in each region who responded that most people can be trusted, narrowtrust or the proportion of people in each region who responded that they trust people they know personally somewhat or completely, and widetrust or the proportion of people in each region who responded that they trust people they meet for the first time somewhat or completely. These measures range from 0 to 1 . We also consider regional ethnic fractionalization (fractionalization) in our regressions. We include the interaction terms between generalizedtrust and narrowtrust (generalizedtrust*narrowtrust), between widetrust and narrowtrust (widetrust* ${ }^{*}$ narrowtrust), between generalizedtrust and fractionalization (generalizedtrust* fractionalization), between narrowtrust and fractionalization (narrowtrust* fractionalization), and between widetrust and fractionalization (widetrust* fractionalization). Control variables include sector-services, dummy Istanbul, and initialGDPgrowth. The variable sector-services is a dummy variable indicating whether the services sector is the dominant sector (or has the highest share in regional GDP). Meanwhile, dummy Istanbul is a dummy variable indicating whether the financial capital, Istanbul, is in the region and initialGDPgrowth is the average regional GDP growth between 2000 and 2003. T-statistics are in parentheses. Standard errors are corrected for heteroskedasticity. Note: $* * *$ denotes significance at less than $1 \%$; $* *$ denotes significance at $5 \%$; denotes significance at $10 \%$. Excluded instruments are the same as in previous estimations. 
Table B2. Marginal effects of generalized trust and wide trust across different levels of narrow trust in Turkey using regional data, $2004-2017$.

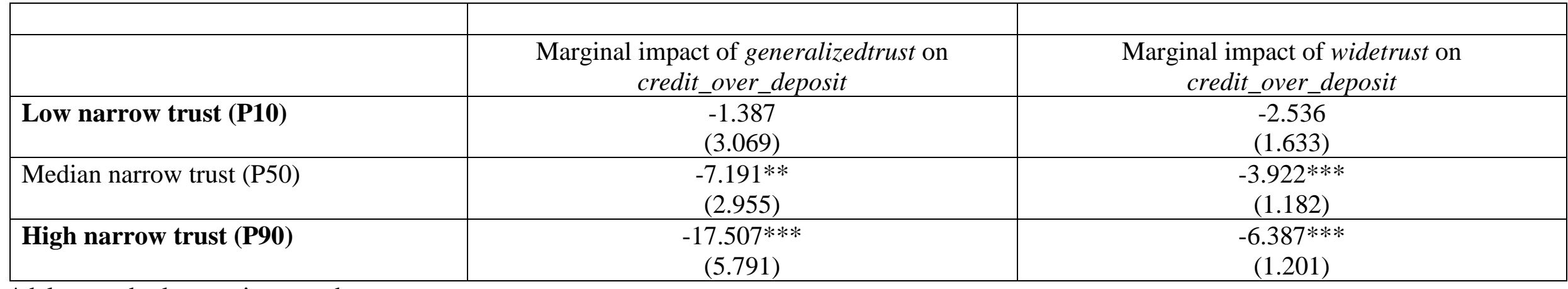

*delta standard errors in parentheses

Table B3. Marginal effect of generalized trust, narrow trust, and wide trust across varying levels of ethnic fractionalization using regional data in Turkey, 2004-2017.

\begin{tabular}{|c|c|c|c|}
\hline Ethnic fractionalization & $\begin{array}{l}\text { Marginal impact of } \\
\text { generalizedtrust on } \\
\text { credit_over_deposit }\end{array}$ & $\begin{array}{l}\text { Marginal impact of } \\
\text { narrowtrust on } \\
\text { credit_over_deposit }\end{array}$ & $\begin{array}{l}\text { Marginal impact of } \\
\text { widetrust on } \\
\text { credit_over_deposit }\end{array}$ \\
\hline Low (P10) & $\begin{array}{c}-14.960 * * * \\
(4.371)\end{array}$ & $\begin{array}{c}-1.834^{*} \\
(0.968)\end{array}$ & $\begin{array}{c}-4.755^{* * *} \\
(1.415)\end{array}$ \\
\hline Median (P50) & $\begin{array}{c}-12.166 * * * \\
(3.625) \\
\end{array}$ & $\begin{array}{c}0.616 \\
(0.566) \\
\end{array}$ & $\begin{array}{c}-2.635^{* *} \\
(1.318) \\
\end{array}$ \\
\hline High (P90) & $\begin{array}{c}-3.160 * * * \\
(2.507)\end{array}$ & $\begin{array}{c}10.765 * * * \\
(3.718)\end{array}$ & $\begin{array}{c}6.145 * * * \\
(1.793)\end{array}$ \\
\hline
\end{tabular}

*delta standard errors in parentheses 